\title{
Los regimenes aduaneros en la Nueva Ley General de Aduanas
}

Marco Antonio Huamán Sialer*

- Profesor de la Pontificia Universidad Católica del Perú, Universidad Nacional Mayor de San Marcos, Universidad de ESAN, Universidad Alas Peruanas, Vocal Presidente de la Sala de Aduanas del Tribunal Fiscal.

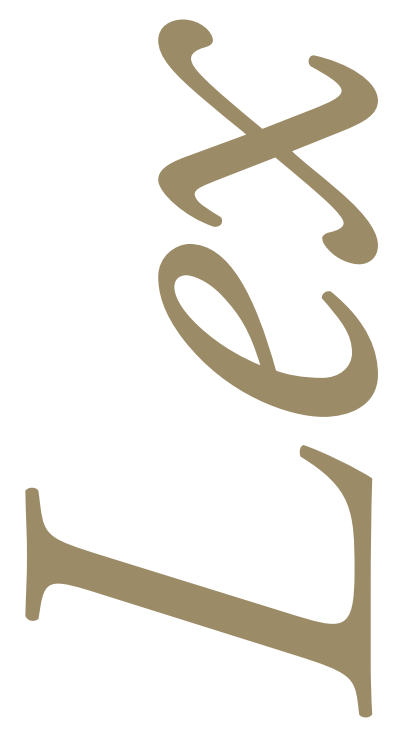




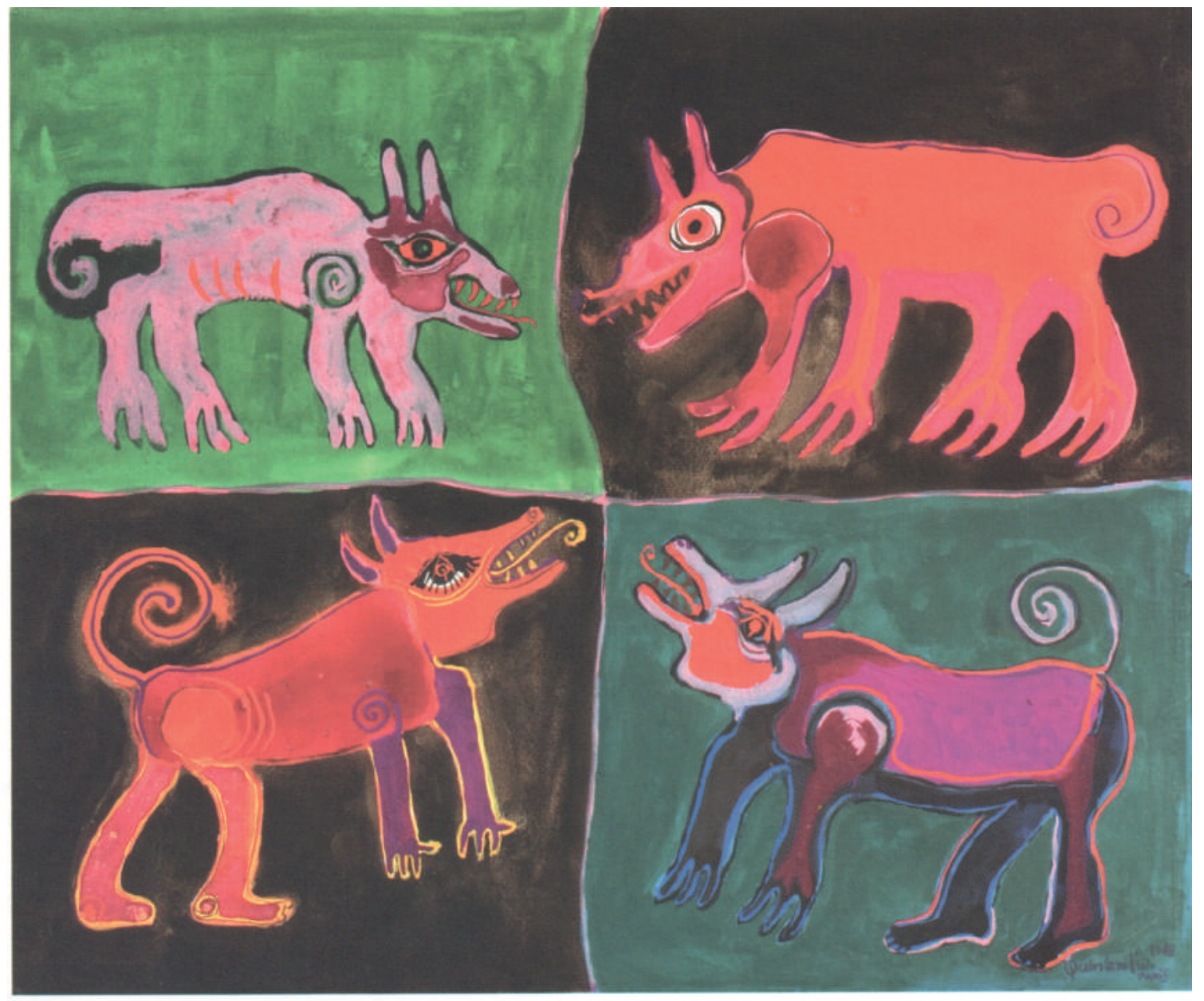

Filigrana entre los perros. Técnica mixta, $1962(38 \mathrm{~cm}$. x $45.5 \mathrm{~cm}$.) 
I 1 presente artículo tiene como propósito realizar un análisis comparativo entre el tratamiento legal sobre regímenes aduaneros presente en la Nueva Ley General de Aduanas, aprobada por Decreto Legislativo No 1053, y el que se encuentra en la Ley General de Aduanas, aprobada por Decreto Legislativo No 809 y cuyo Texto Único Ordenado fue aprobado por Decreto Supremo No 129-2004-EF.

\section{Antecedentes y objetivos}

Los antecedentes más mediatos que tenemos de los regímenes aduaneros, aunque con la denominación de operaciones aduaneras, los encontramos en el Código de Procedimientos Aduaneros expedido el 21 de Abril de 1926 creado por Ley $\mathrm{N}^{\circ} 4380$; luego, en la primera Ley General de Aduanas aprobada por el Decreto Ley N²0165 del 2 de Octubre de 1973; posteriormente, en el Decreto Legislativo $\mathrm{N}^{\circ} 503$ de 30 de noviembre de 1988, que aprueba la Ley General de Aduanas; luego, el Decreto Legislativo $N^{\circ} 722$ (08 de Noviembre de 1991) que aprueba la Ley General de Aduanas, y el Decreto Legislativo No809 (19 de Abril de 1996 con vigencia en Diciembre de 1996).

El convenio internacional para la simplificación y armonización de los regímenes aduaneros, conocido internacionalmente como Convenio de Kyoto, adoptado el 18 de mayo de 1973, ha servido de base para la regulación, en cuanto a regímenes aduaneros, a partir de del Decreto Legislativo $\mathrm{N}^{\circ} 503$; , luego, las sucesivas leyes de facto lo han ido incorporando progresivamente a la legislación aduanera.

\section{Análisis de las modificatorias}

El 27 de junio de 2008, mediante el Decreto Legislativo № 1053, se aprueba la nueva Ley General de Aduanas, (en adelante nueva ley), la cual se encuentra vigente en relación a la regulación sobre los Regímenes Aduaneros (Sección Tercera) desde el 17 de marzo de 2009, 
según el artículo $2^{\circ}$ del Decreto Supremo No 010-2009-EF que aprueba el Reglamento de la nueva Ley General de Aduanas, modificado por el Decreto Supremo No 319-2009-EF ${ }^{1}$ y Decreto Supremo No 096-2010-EF².

Con la nueva Ley de Aduanas, se ha variado las denominaciones de los regímenes aduaneros. Así, en la cuarta disposición complementaria final del Decreto Legislativo № 1053 se señala la siguiente correlación sobre las modificaciones realizadas:

\begin{tabular}{|l|l|}
\hline \multicolumn{1}{|c|}{ Denominaciones nuevas } & \multicolumn{1}{c|}{ Denominaciones anteriores } \\
\hline Importación para el consumo & Importación \\
\hline Reimportación en el mismo estado & Exportación Temporal \\
\hline $\begin{array}{l}\text { Admisión temporal para reexportación en el } \\
\text { mismo estado }\end{array}$ & $\begin{array}{l}\text { Importación Temporal para reexportación en el } \\
\text { mismo estado }\end{array}$ \\
\hline Exportación definitiva & Exportación \\
\hline $\begin{array}{l}\text { Exportación temporal para reimportación en } \\
\text { el mismo estado }\end{array}$ & Exportación Temporal \\
\hline
\end{tabular}

i Artículo 2.- Vigencia

El presente Reglamento entrará en vigencia a los sesenta (60) días calendario contados a partir del día siguiente de su publicación, con excepción de los capítulos III, V y VI del Tírulo II de la Sección Segunda, la Sección Cuarta, la Sección Quinta, el Capítulo IV de la Sección Sexta y el Tírulo II de la Sección Décima, que entrarán en vigencia a partir del 22 de febrero de 2010, conforme al siguiente cronograma, por lo cual los artículos correspondientes del Texto Único Ordenado del Decreto Legislativo No 809 aprobado por Decreto Supremo No 129-2004-EF y normas modificatorias seguirán vigentes en las respectivas circunscripciones hasta el 25 de abril de 2010 según cste cronograma:

22 de Febrero : Aduanas de llo y Paita

08 de Marzo : Aduanas de Chimbote, Mollendo, Pisco y Salaverry

29 de Marzo : Aduana Marítima del Callao

12 de Abril : Aduana Aérea del Callao

26 de Abril : Aduanas de Arequipa, Chiclayo, Cusco, Iquitos, Postal del Callao, Pucallpa, Puerto Maldonado, Puno, Tacna, Tarapoto, Tumbes y la Agencia Aduanera La Tina.

2 Artículo $1^{\circ}$. El proceso de despacho anticipado en el régimen de importación para el consumo, de acuerdo a lo dispuesto en la Ley General de Aduanas aprobada por el Decreto Legislativo N ${ }^{\circ} 1053$ y su Reglamento, rige a partir del 29 de marzo de 2010 en la Intendencia de Aduana Marítima del Callao y del 12 de abril de 2010 en la Intendencia de Aduana Aérea del Callao.

Para los procesos no comprendidos en el párrafo anterior, la Superintendencia Nacional de Administración "Tributaria - SUNAT, con opinión favorable del Ministerio de Economía y Finanzas, mediante Resolución de Superintendencia, en un plazo no mayor a treinta (30) días calendario contados a partir de la fecha de publicación del presente Decreto Supremo, aprobará el plan y el cronograma para la implementación en forma progresiva del nuevo proceso de despacho aduanero en las intendencias de aduana citadas en el párrafo precedente y en las intendencias de aduana de Arequipa, Chiclayo, Cusco, Iquitos, Postal del Callao, Pucallpa, Puerto Maldonado, Puno, Tacna, Tarapoto, Tumbes y la Agencia Aduanera La Tina.

Dicha implementación progresiva culminará el 1 de octubre de 2010. 


\begin{tabular}{|l|l|}
\hline $\begin{array}{l}\text { Admisión temporal para perfeccionamiento } \\
\text { activo }\end{array}$ & $\begin{array}{l}\text { Admisión temporal para perfeccionamiento } \\
\text { activo }\end{array}$ \\
\hline $\begin{array}{l}\text { Exportación temporal para perfeccionamiento } \\
\text { pasivo }\end{array}$ & Exportación Temporal \\
\hline Drawback & Drawback \\
\hline $\begin{array}{l}\text { Reposición de mercancías con franquicia } \\
\text { arancelaria }\end{array}$ & Reposición de mercancías en franquicia \\
\hline Depósito aduanero & Depósito de aduana \\
\hline Tránsito aduanero & Tránsito \\
\hline Transbordo & Transbordo \\
\hline Reembarque & Reembarque \\
\hline Regímenes aduaneros especiales o de excepción & Destinos aduaneros especiales o de excepción \\
\hline
\end{tabular}

La nueva ley deja de lado la clasificación que establecía la Ley General de Aduanas aprobada por Decreto Legislativo No 809, cuyo Texto Único Ordenado fue aprobado por Decreto Supremo No 129-2004-EF, derogada en cuento a la regulación sobre regímenes (en adelante ley derogada), clasificaba de la siguiente manera: Regímenes definitivos, temporales, suspensivos y de perfeccionamiento, que agrupaba los regímenes de la siguiente forma:

\section{Regímenes Definitivos:}

- Importación

- Exportación

\section{Regímenes Suspensivos:}

- Tránsito

- Transbordo

- Depósito de aduana

Regímenes Temporal

- Importación temporal para reexportación en el mismo estado

- Exportación temporal 
Regímenes de Perfeccionamiento:

- Admisión temporal para perfeccionamiento activo

- Drawback

- Reposición de mercancías en franquicia

Además de estos regímenes, la ley de aduanas también derogada contemplaba el reembarque, denominándolo operación aduanera, y los tratamientos especiales, llamados destinos especiales. Con la nueva ley de aduanas, los regímenes son clasificados en: Regímenes de importación, de exportación, de perfeccionamiento, de depósito, de tránsito y los regímenes aduaneros o de excepción.

Regímenes de importación:

- Importación para el consumo;

- Reimportación en el mismo estado; y

- Admisión temporal para reexportación en el mismo estado.

Regímenes de de exportación:

- Exportación definitiva; y

- Exportación temporal para reimportación en el mismo estado.

Regímenes de perfeccionamiento:

- Admisión temporal para perfeccionamiento activo;

- Exportación temporal para perfeccionamiento pasivo;

- Drawback; $y$

- Reposición de mercancías con franquicia arancelaria.

Régimen de depósito:

- Depósito aduanero.

Regímenes de tránsito:

- Tránsito aduanero;

- Transbordo; y

- Reembarque.

Como observamos en los regímenes aduaneros, la figura del reembarque, denominada operación aduanera con la ley derogada, ahora es considerada como un régimen aduanero. 
De igual manera, los destinos especiales son calificados como regímenes aduaneros o de excepción con la nueva ley.

Este cambio en la denominación de los regímenes aduaneros concuerda con la denominación que tiene sobre dichos tratamientos la Decisión No 671 referida a la Armonización de Regímenes Aduaneros de la Comisión de la Comunidad Andina, norma comunitaria que ha entrado en vigencia el 1 de junio del 2010 conforme a lo establecido en la Disposición Final del mencionado dispositivo sustituido por la Decisión № 716 de la misma comisión.

A continuación, revisaremos los artículos referidos a los regímenes aduaneros de la nueva Ley General de Aduanas.

\section{Regímenes de Importación:}

\subsection{De la importación para el consumo}

\begin{tabular}{|c|c|}
\hline NUEVA LEY & LEY DEROGADA \\
\hline $\begin{array}{l}\text { TÍTULO II } \\
\qquad \begin{array}{l}\text { REGÍMENES DE IMPORTACIÓN } \\
\text { CAPÍTULO I }\end{array} \\
\text { De la importación para el consumo } \\
\text { Artículo } 49^{\circ} \text {.- Importación para el consumo } \\
\text { Régimen aduanero que permite el ingreso de mer- } \\
\text { cancías al territorio aduanero para su consumo, } \\
\text { luego del pago o garantía según corresponda, de } \\
\text { los derechos arancelarios y demás impuestos apli- } \\
\text { cables, así como el pago de los recargos y multas } \\
\text { que hubieren, y del cumplimiento de las formali- } \\
\text { dades y otras obligaciones aduaneras. } \\
\text { Las mercancias extranjeras se considerarán nacio- } \\
\text { nalizadas cuando haya sido concedido el levante. } \\
\text { Artículo } 50^{\circ} \text { - - Importación a zonas de tratamien- } \\
\text { to aduanero especial } \\
\text { Las mercancías extranjeras importadas para el } \\
\text { consumo en zonas de tratamiento aduanero espe- }\end{array}$ & $\begin{array}{l}\qquad \begin{array}{l}\text { CAPITULO II } \\
\text { De la Importación }\end{array} \\
\text { Artículo } 52^{\circ} \text {.- Es el régimen aduanero que permi- } \\
\text { te cl ingreso legal de mercancías provenientes del } \\
\text { exterior, para ser destinadas al consumo. } \\
\text { Las mercancias extranjeras se considerarán nacio- } \\
\text { nalizadas cuando haya sido concedido el levante, } \\
\text { momento en que culmina el despacho de impor- } \\
\text { tación. } \\
\text { El despacho urgente de los envíos de socorro y ur- } \\
\text { gencia se efectuará limitando el control de la au- } \\
\text { toridad aduancra al mínimo necesario, de acuerdo } \\
\text { a las condiciones, límites, entre otros aspectos que } \\
\text { establezca el Reglamento. } \\
\text { Artículo } 53^{\circ} \text {.- Las mercancías extranjeras impor- } \\
\text { tadas en zonas de tratamiento aduanero especial se } \\
\text { considerarán nacionalizadas sólo respecto a dichos } \\
\text { territorios. }\end{array}$ \\
\hline
\end{tabular}


cial se considerarán nacionalizadas sólo respecto a dichos territorios.

Para que dichas mercancías se consideren nacionalizadas en el territorio aduanero deberán someterse a la legislación vigente en el pais, sirviéndoles como pago a cuenta los tributos que hayan gravado su importación para el consumo.
Para que dichas mercancías se consideren nacionalizadas en el territorio aduanero deberán someterse a la legislación general vigente en el país, sirviéndoles como pago a cuenta los triburos que hayan gravado su importación.

En cuanto a este artículo referido a la definición del régimen de importación, cabe resaltar que, según el nuevo modelo del despacho aduanero, ya no se hace la precisión que con la obtención del levante termina el despacho aduanero, ya que, según lo previsto en la nueva ley, se puede obtener el levante sin que haya terminado el despacho aduanero.

$\mathrm{Al}$ respecto, cabe precisar que, según el artículo $2^{\circ}$ de la nueva Ley General de Aduanas, el levante es el acto por el cual la autoridad aduanera autoriza a los interesados a disponer de las mercancías de acuerdo con el régimen aduanero solicitado.

El último párrafo del artículo $131^{\circ}$ de la nueva ley señala que, en cualquiera de sus modalidades, el despacho concluirá dentro de los tres meses siguientes contados desde la fecha de la destinación aduanera, pudiendo ampliarse hasta un año en casos debidamente justificados. Por esta razón, la normatividad no condiciona la obtención del levante para dar por terminada el despacho aduanero.

\subsection{Régimen de reimportación en el mismo Estado}

\begin{tabular}{|c|l|}
\hline NUEVA LEY & \multicolumn{1}{c|}{ LEY DEROGADA } \\
\hline $\begin{array}{c}\text { CAPÍTULO II } \\
\text { De la reimportación en el mismo Estado }\end{array}$ & \multicolumn{1}{c|}{$\begin{array}{c}\text { SECCION II } \\
\text { Exportación Temporal }\end{array}$} \\
$\begin{array}{l}\text { Arrículo } 51^{\circ} \text { - } \text { Reimportación en el mismo estado } \\
\begin{array}{l}\text { Régimen aduanero que permite el ingreso al te- } \\
\text { rritorio aduanero de mercancías exportadas con } \\
\text { carácter definitivo sin el pago de los derechos } \\
\text { arancelarios y demás impuestos aplicables a la im- } \\
\text { portación para el consumo y recargos de corres- } \\
\text { ponder, con la condición de que no hayan sido }\end{array}\end{array}$ & $\begin{array}{l}\text { Artículo } 68^{\circ} \text { - }- \text { Se considerará como tempo- } \\
\text { ral una exportación, cuando se acredite que } \\
\text { la mercancía exportada no fue aceptada en el } \\
\text { país de destino. }\end{array}$ \\
\hline
\end{tabular}


sometidas a ninguna transformación, elaboración o reparación en el extranjero, perdiéndose los beneficios que se hubieren otorgado a la exportación. rrafo anterior será de doce (12) meses, contado a partir de la fecha del término del embarque de la mercancía.
Artículo 52\%.- Plazo

El plazo máximo para acogerse a lo dispuesto en el artículo anterior será de doce (12) meses contado a partir de la fecha del término del embarque de la mercancía exportada.

\section{SECCION II \\ Exportación Temporal}

(...)

Artículo $68^{\circ}$.- Se considerará como temporal una exportación, cuando se acredite que la mercancía exportada no fue aceptada en el país de destino.

El plazo para acogerse a lo dispuesto en el párrafo anterior será de doce (12) meses, contado a partir de la fecha del término del embarque de la mercancía.

Este tratamiento legal, de reimportación en el mismo estado, era una figura que resultaba como consecuencia de la exportación temporal especial prevista en el artículo $68^{\circ}$ de la anterior ley, especial porque nace de una exportación definitiva pero por el hecho de no ser aceptada en el país de destino se consideraba como exportación temporal, algunos la denominaban "exportación frustrada".

El plazo para aplicar este régimen es el mismo, de 12 meses contado a partir de la fecha del término del embarque de la mercancía exportada, pero se hace la precisión que cuando se aplica este régimen, se pierde los beneficios que se hubiesen otorgado a la exportación. 


\subsection{Régimen de admisión temporal para reexportación en el mismo Estado}

\begin{tabular}{|c|c|}
\hline NUEVA LEY & LEY DEROGADA \\
\hline $\begin{array}{l}\text { CAPITULO III } \\
\text { De la admisión temporal para reexportación en el } \\
\text { mismo Estado } \\
\text { Artículo } 53^{\circ} \text {.- Admisión temporal para reexporta- } \\
\text { ción en el mismo estado } \\
\text { Régimen aduanero que permite el ingreso al territo- } \\
\text { rio aduanero de ciertas mercancías, con suspensión } \\
\text { del pago de los derechos arancelarios y demás im- } \\
\text { puestos aplicables a la importación para el consu- } \\
\text { mo y recargos de corresponder, siempre que sean } \\
\text { identificables y estén destinadas a cumplir un fin } \\
\text { determinado en un lugar específico para ser reex- } \\
\text { portadas en un plazo determinado sin experimentar } \\
\text { modificación alguna, con excepción de la deprecia- } \\
\text { ción normal originada por el uso que se haya hecho } \\
\text { de las mismas. } \\
\text { Las mercancías que podrán acogerse al presente } \\
\text { régimen serán determinadas de acuerdo al listado } \\
\text { aprobado por Resolución Ministerial de Economía } \\
\text { y Finanzas. } \\
\text { Artículo } 54^{\circ} \text {.- Contratos o convenios con el Estado } \\
\text { La admisión temporal para reexportación en el mis- } \\
\text { mo estado, realizada al amparo de contratos con } \\
\text { el Estado o normas especiales, así como convenios } \\
\text { suscritos con el Estado sobre cl ingreso de mercan- } \\
\text { cías para investigación científica destinadas a enti- } \\
\text { dades del Estado, universidades e instituciones de } \\
\text { educación superior, debidamente reconocidas por } \\
\text { la autoridad competente, se regulará por dichos } \\
\text { contratos o convenios y en lo que no se oponga a } \\
\text { ellos, por lo dispuesto en el presente Decreto Legis- } \\
\text { lativo y su Reglamento. } \\
\text { Artículo } 55^{\circ} \text {-- Accesorios, partes y repuestos } \\
\text { Los accesorios, partes y repuestos que no se im- } \\
\text { porten conjuntamente con los bienes de capital } \\
\text { admitidos temporalmente podrán ser sometidos al } \\
\text { presente régimen, siempre y cuando se importen } \\
\text { dentro del plazo autorizado. } \\
\text { Artículo } 56^{\circ} \text { - Plazo } \\
\text { La admisión temporal para reexportación en el } \\
\text { mismo estado es automáticamente autorizada con }\end{array}$ & $\begin{array}{l}\text { CAPITULO V } \\
\text { Regímenes Temporales } \\
\text { SECCION I } \\
\text { Importación Temporal para } \\
\text { Reexportación en el mismo Estado } \\
\text { Artículo 63o - Es el régimen aduanero que permite } \\
\text { el ingreso al territorio nacional, con suspensión del } \\
\text { pago de los derechos arancelarios y demás impuestos } \\
\text { aplicables a la importación, de las mercancías extran- } \\
\text { jeras que se determinen por Resolución Ministerial } \\
\text { de Economía y Finanzas, siempre que sean identifi- } \\
\text { cables y estén destinadas a cumplir un fin determi- } \\
\text { nado en un lugar específico, para ser reexportadas en } \\
\text { el plazo establecido sin sufrir modificación alguna en } \\
\text { su naturaleza, excepto la depreciación normal como } \\
\text { consecuencia del uso. } \\
\text { La importación temporal será automáticamente au- } \\
\text { torizada por el plazo solicitado por el beneficiario, } \\
\text { sin exceder el plazo de dieciocho (18) meses con la } \\
\text { presentación de la Declaración y de la Garantía con } \\
\text { una vigencia igual a la del plazo solicitado. Si este } \\
\text { fuese menor las prórrogas serán aprobadas automá- } \\
\text { ticamente antes del vencimiento del plazo otorgado, } \\
\text { con la sola renovación de la garantía sin exceder en } \\
\text { total el plazo máximo. } \\
\text { Los solicitantes deberán constituir garantía por una } \\
\text { suma equivalente a los Derechos Arancelarios y de- } \\
\text { más impuestos respectivos y, cuando corresponda, } \\
\text { a los derechos antidumping o compensatorios, más } \\
\text { un interés compensatorio sobre dicha suma, igual al } \\
\text { promedio diario de la TAMEX por día, proyectado } \\
\text { desde la fecha de numeración de la declaración de } \\
\text { importación temporal hasta la fecha de vencimiento } \\
\text { del plazo del régimen, a fin de responder por la deu- } \\
\text { da tributaria aduanera existente al momento de la } \\
\text { nacionalización. } \\
\text { Las personas naturales o jurídicas que soliciten la } \\
\text { importación temporal y que califiquen dentro del }\end{array}$ \\
\hline
\end{tabular}


la presentación de la declaración y de la garantía a satisfacción de la SUNAT con una vigencia igual al plazo solicitado y por un plazo máximo de dieciocho (18) meses computado a partir de la fecha del levante. Si el plazo fuese menor, las prórrogas serán aprobadas automáticamente con la sola renovación de la garantía antes del vencimiento del plazo otorgado y sin exceder el plazo máximo.

Para el material de embalaje de productos de exportación, se podrá solicitar un plazo adicional de hasta seis (6) meses.

En los casos establecidos en el Artículo $54^{\circ}$ el plazo del régimen se sujetará a lo establecido en los contratos, normas especiales o convenios suscritos con el Estado a que se refieren dicho artículo.

Artículo $57^{\circ}$.- Garantía

Para autorizar el presente régimen se deberá constituir garantía a satisfacción de la SUNAT por una suma equivalente a los derechos arancelarios y demás impuestos aplicables a la importación para el consumo y recargos de corresponder, más un interés compensatorio sobre dicha suma, igual al promedio diario de la TAMEX por día proyectado desde la fecha de numeración de la declaración hasta la fecha de vencimiento del plazo del régimen, a fin de responder por la deuda existente al momento de la nacionalización.

Artículo $58^{\circ}$ - Buen contribuyente de la admisión temporal para reexportación en el mismo estado Las personas naturales o jurídicas que soliciten el presente régimen podrán garantizar sus obligaciones en la forma y modo que se establezca mediante Decreto Supremo refrendado por el Ministro de Economia y Finanzas.

Artículo $59^{\circ}$.- Conclusión del régimen

El presente régimen concluye con:

a) La reexportación de la mercancía, en uno o varios envíos y dentro del plazo autorizado;

b) El pago de los derechos arancelarios y demás impuestos aplicables y recargos de corresponder, más el interés compensatorio igual al promedio diario de la TAMEX por día, computado a partir de la fecha de numeración de la declaración hasta la fecha de pago, conforme a lo establecido por la Administración Aduanera, en cuyo caso se dará por nacionalizada la mercancía;
Régimen de Buenos Contribuyentes, podrán respaldar sus obligaciones en la forma y modo, que se establezca mediante Decreto Supremo refrendado por el Ministro de Economía y Finanzas.
Artículo $64^{\circ},-\mathrm{El}$ régimen concluye con la reexportación de las mercancías por el beneficiario, en uno o varios envíos $y$, dentro del plazo autorizado.

Excepcionalmente el régimen puede concluir con:

a) El pago, previa liquidación, de los tributos y los derechos antidumping o compensatorios de corresponder, más el interés compensatorio igual al promedio diario de la TAMEX por día, computado a partir de la fecha de numeración de la declaración de importación temporal hasta la fecha de pago; en 
c) La destrucción total o parcial de la mercancía por caso fortuito o fuerza mayor debidamente acreditada, o a solicitud del beneficiario la cual debe ser previamente aceptada por la autoridad aduanera conforme a lo establecido en el Reglamento;

Si al vencimiento del plazo autorizado no se hubiera concluido con el régimen de acuerdo a lo señalado en el párrafo precedente, la SUNAT automáticamente dará por nacionalizada la mercancía, por concluido el régimen, y ejecutará la garantía. Tratándose de mercancía restringida que no cuenten con la autorización de ingreso permanente al país, la Administración Aduanera informará al sector competente para que proceda a su comiso de acuerdo a la normatividad respectiva. cuyo caso se dará por nacionalizada la mercancía. La SUNAT establecerá la formalidad y el procedimiento para concluir el Régimen.

b) La destrucción total o parcial de la mercancía en caso fortuito, fuerza mayor o a solicitud del beneficiario, debidamente acreditada y aceptada por la autoridad aduanera, conforme lo establece el Reglamento.

Si al vencimiento del plazo autorizado no se hubiera concluido con el régimen de acuerdo a lo señalado en los párrafos precedentes, la SUNAT dará por nacionalizada automáticamente la mercancía y concluido el régimen de importación temporal, ejecutándose la garantía conforme a lo establecido en el artículo $63^{\circ}$ de la presente Ley.

Tratándose de material de embalaje de productos de exportación, en casos debidamente justificados se podrá solicitar un plazo adicional, de hasta seis (6) meses, al señalado en el segundo párrafo del artículo precedente.

Como observamos, este régimen ha cambiado su denominación, pues en la ley derogada se le denominaba Importación Temporal para Reexportación en el mismo Estado; con la nueva ley, se le denomina Admisión Temporal para Reexportación en el mismo Estado.

La nueva ley en su artículo $54^{\circ}$ precisa el tratamiento sobre los contratos y convenios con el Estado. Este tratamiento no se encontraba previsto en la norma derogada, sino en el reglamento de esta cuando, en el artículo $113^{\circ}$ del Decreto Supremo No 011-2005-EF, señalaba que "Las normas de la presente Sección son aplicables a las importaciones temporales efectuadas al amparo de contratos suscritos con el Estado o normas especiales, en todo lo que no se oponga a lo establecido en éstos".

Como se aprecia, la regulación actual no solo se refiere a contratos sino a convenios que realice el Estado, referidos a el ingreso de mercancías para investigación científica destinadas a entidades del Estado, universidades e instituciones de educación superior, debidamente reconocidas por la autoridad competente.

También, la nueva ley regula el ingreso de los accesorios, partes y repuestos, cosa que no se encontraba regulada en la norma derogada. Se señala, además, que cuạndo dichas mercancías 
no se importen conjuntamente con los bienes de capital admitidos temporalmente, podrán ser sometidas al presente régimen, siempre y cuando se importen dentro del plazo autorizado.

Finalmente, debemos resaltar que con la nueva ley el cómputo del plazo del régimen se realiza a partir de la fecha del levante. En cambio, en la ley derogada no se establecía la manera de realizar el cómputo; sin embargo en el artículo $101^{\circ}$ de su reglamento se señalaba: "El plazo de la importación temporal se cuenta partir de la fecha de la numeración de la declaración”.

\section{Regímenes de Exportación}

\subsection{De la exportación definitiva}

TÍTULO III
REGÍMENES DE EXPORTACIÓN
CAPÍTULO I
De la exportación definitiva
Artículo $60^{\circ}$ - Exportación definitiva
Régimen aduanero que permite la salida del te-
rritorio aduanero de las mercancías nacionales o
nacionalizadas para su uso o consumo definitivo
en el exterior.
La exportación definitiva no está afecta a ningún
tributo.

Artículo $54^{\circ}$.- Es el régimen aduanero aplicable a las mercancías en libre circulación que salen del territorio aduanero para su uso o consumo definitivo en el exterior.

Considerase como exportación de mercancías a las operaciones swap a que se refiere el numeral 2 del artículo $33^{\circ}$ del Texto Único Ordenado de la Ley del Impuesto General a las Ventas e Impuesto Selectivo al Consumo aprobado mediante Decreto Supremo $\mathrm{N}^{\circ} 055-99-\mathrm{EF}$, modificado por la Ley $\mathrm{N}^{\circ}$ 27625 .

Las mercancías deben embarcarse dentro del plazo de diez (10) días, contados a partir del día siguiente de la numeración de la declaración, pudiendo prorrogarse automáticamente por diez (10) días adicionales, a solicitud del interesado. La regularización del régimen se efectuará en la forma y plazos que establezca el Reglamento.

La exportación de bienes no está afecta a ningún triburo. 
Artículo $61^{\circ}$ - Plazos

Las mercancías deben ser embarcadas dentro del plazo de treinta (30) días calendario contado a partir del día siguiente de la numeración de la declaración.

La regularización del régimen se realizará dentro del plazo de treinta (30) días calendario contado a partir del día siguiente de la fecha del término del embarque, de acuerdo a lo establecido en el Reglamento.

Artículo $62^{\circ}$.- Mercancía prohibida o restringida La exportación definitiva no procederá para las mercancias que sean patrimonio cultural y/o histórico de la nación, mercancías de exportación prohibida y para las mercancías restringidas que no cuenten con la autorización del sector competente a la fecha de su embarque.

Artículo $63^{\circ}$.- Otras operaciones consideradas como exportación definitiva

Considérese como exportación definitiva de mercancias a las operaciones a que se refiere los numerales 2 y 5 del artículo $33^{\circ} \mathrm{del}$ Texto Único Ordenado de la Ley del Impuesto General a las Ventas e Impuesto Selectivo al Consumo aprobado mediante Decreto Supremo $N^{\circ} 055-99-\mathrm{EF}$, modificado por la Ley $\mathrm{N}^{\circ} 27625$ y la Ley $\mathrm{N}^{\circ} 28462$.

\section{CAPITULO III \\ De la Exportación}

Artículo $54^{\circ}$.- Es el régimen aduanero aplicable a las mercancías en libre circulación que salen del territorio aduanero para su uso o consumo definitivo en el exterior. Considérase como exportación de mercancías a las operaciones swap a que se refiere el numeral 2 del artículo $33^{\circ}$ del Texto Único Ordenado de la Ley del Impuesto General a las Ventas e Impuesto Selectivo al Consumo aprobado mediante Decreto Supremo N055-99-EF, modificado por la Ley $\mathrm{N}^{\circ} 27625$.

Las mercancías deben embarcarse dentro del plazo de diez (10) días, contados a partir del día siguiente de la numeración de la declaración, pudiendo prorrogarse automáticamente por diez (10) días adicionales, a solicitud del interesado. La regularización del régimen se efectuará en la forma y plazos que establezca el Reglamento. $\left.{ }^{* * *}\right)$

La exportación de bienes no está afecta a ningún tributo.

\section{Nota: Reglamento del TUO DS No 011-2005-EF}

Artículo $85^{\circ}$.- La regularización del régimen se realiza con la transmisión por vía electrónica de la información complementaria de la declaración y la presentación de los documentos que la sustentan a satisfacción de la autoridad aduanera, dentro del plazo de quince (15) días contados a partir del día siguiente de la fecha de término del embarque.

Artículo $55^{\circ}$.- La exportación definitiva no procederá para las mercancías que sean patrimonio cultural y/o histórico de la nación así como otras de exportación prohibida y restringida. 
Es necesario resaltar que la nueva ley incorpora, como exportación, el supuesto expresado en el numeral 5 del artículo $33^{\circ}$ del Texto Único Ordenado de la Ley del Impuesto General a las Ventas e Impuesto Selectivo al Consumo aprobado mediante Decreto Supremo $N^{\circ} 055$ 99-EF, modificado por la Ley $N^{\circ} 27625$ y la Ley $N^{\circ} 28462$, consistente en: "La venta a las empresas que presten el servicio de transporte internacional de carga y/o de pasajeros, de los bienes destinados al uso o consumo de los pasajeros y miembros de la tripulación a bordo de las naves de transporte marítimo o aéreo; así como de los bienes que sean necesarios para el funcionamiento, conservación y mantenimiento de los referidos medios de transporte, incluyendo, entre otros bienes, combustibles, lubricantes y carburantes. Por decreto supremo refrendado por el Ministerio de Economía y Finanzas se establecerá la lista de bienes sujetos al presente régimen."

Asimismo, el plazo para embarcar la mercancía fue cambiado de 10 días (con la opción de prorrogar 10 días más) a 30 días calendario, otorgándole al exportador un plazo más razonable para poder materializar el embarque de la mercancía, acorde a las reales prácticas operativas.

La norma derogada no precisaba si el plazo eran días hábiles o calendario, por lo que se entendía como días hábiles, conforme lo señalado en la Norma XII del Título Preliminar del Texto Único Ordenado del Código Tributario aprobado por Decreto Supremo No 135-99EF; ahora, con la nueva ley se precisa que se trata de días calendarios.

También, se modificó el plazo para regularizar el régimen (no se precisaba si eran días hábiles o calendarios, por lo que se entendía como hábiles), según lo establecido en el artículo $85^{\circ}$ del reglamento de la ley derogada, de 15 días a 30 días calendarios.

\subsection{De la exportación temporal para reimportación en el mismo Estado}

\begin{tabular}{|c|c|}
\hline $\begin{array}{l}\text { CAPÍTULO II } \\
\text { De la exportación temporal para reimportación } \\
\text { en el mismo Estado } \\
\text { Artículo } 64^{\circ} \text { - Exportación temporal para reimpor- } \\
\text { tación en el mismo estado. } \\
\text { Régimen aduanero que permite la salida temporal } \\
\text { del territorio aduanero de mercancías nacionales o } \\
\text { nacionalizadas con la finalidad de reimportarlas en } \\
\text { un plazo determinado, sin haber experimentado } \\
\text { modificación alguna, con excepción del deterioro }\end{array}$ & $\begin{array}{l}\text { CAPITULO V } \\
\text { Regímenes Temporales } \\
(\ldots) \\
\text { SECCION II } \\
\text { Exportación Temporal } \\
\text { Articulo } 65^{\circ} \text { - Es el Régimen Aduanero que per- } \\
\text { mite la salida temporal al exterior de mercancías } \\
\text { nacionales o nacionalizadas con la obligación de }\end{array}$ \\
\hline
\end{tabular}


normal por su uso.

No podrá incluirse en este régimen las mercancías cuya salida del país estuviera restringida o prohibida, salvo que estén destinadas a exposiciones o certámenes de carácter artístico, cultural, deportivo o similar y que cuente con la autorización del sector competente.

Artículo $65^{\circ}$.-Plazo

El plazo de la exportación temporal para reimportación en el mismo estado será automáticamente autorizado por doce (12) meses, computado a partir de la fecha del término del embarque de la mercancía, dentro del cual deberá efectuarse la reimportación.

El plazo señalado en el párrafo anterior podrá ser ampliado por la Administración Aduanera, a solicitud del interesado, en casos debidamente justificados.

Artículo 66\%.- Mercancías reimportadas

Las mercancías exportadas bajo este régimen aduanero al ser reimportadas no estarán sujetas al pago de los derechos arancelarios y demás tributos aplicables a la importación para el consumo y recargos de corresponder

Artículo $67^{\circ}$.- Conclusión del régimen

$\mathrm{El}$ presente régimen concluye con:

a) La reimportación de la mercancía dentro del plazo autorizado;

b) La exportación definitiva de la mercancía dentro del plazo autorizado, para lo cual se deberá cumplir con las formalidades establecidas en el Reglamento, con lo que se dará por regularizado el régimen.

Si al vencimiento del plazo autorizado o de la prórroga de ser el caso, no se hubiera concluido con el régimen de acuerdo a lo señalado en el párrafo precedente, la autoridad aduanera automáticamente dará por exportada en forma definitiva la mercancía y concluido el régimen. reimportarlas en un plazo determinado, en el mismo estado o luego de haber sido sometidas a una reparación, cambio o mejoramiento de sus características.

El plazo de la exportación temporal será automáticamente concedido por doce (12) meses, computados a partir de la fecha del término del embarque de la mercancía, dentro del cual deberá efectuarse la reimportación.

El plazo señalado en el párrafo anterior podrá ser ampliado por ADUANAS, a solicitud del interesado, en casos debidamente justificados. Vencido el plazo de exportación temporal, o el de la prórroga en su caso, la mercancía se considerará automáticamente exportada en forma definitiva.

Artículo 67\%.- Los beneficiarios del Régimen de Exportación Temporal podrán solicitar la exportación definitiva de la mercancía dentro del plazo temporalmente concedido, para lo cual deberán cumplir con las formalidades establecidas en la presente Ley y su Reglamento, con lo que se dará por regularizado el régimen.

No podrá incluirse en el Régimen de Exportación Temporal las mercancías cuya salida del país estuviera restringida o prohibida, salvo que estén destinadas a exposiciones o certámenes de carácter artístico, cultural, deportivo o similares y que cuente con la autorización de las autoridades respectivas.

Artículo 69.- Cuando las mercancías exportadas temporalmente se reimporten, después de ser reparadas o perfeccionadas en el exterior, la determinación de la base imponible para el cobro de los derechos arancelarios y demás tributos se calculará sobre el monto del valor agregado. 
Los diversos supuestos que contenía el régimen de exportación temporal con la norma derogada han sido divididos y se han formado tres regímenes aduaneros: el de reimportación en el mismo Estado (ubicado dentro de los regímenes de importación), el presente régimen de exportación temporal para reimportación en el mismo Estado y el régimen de exportación temporal para perfeccionamiento pasivo (ubicado dentro de los regímenes de perfeccionamiento).

Como su nombre lo señala, este régimen permite la salida al exterior de mercancías y su retorno en el mismo Estado, salvo por el deterioro normal por el uso.

En este régimen, la reimportación de las mercancías no está sujeta a pago de los derechos arancelarios y demás tributos aplicables a la importación para el consumo y recargos de corresponder.

La conclusión normal de este régimen se da con la reimportación de la mercancía dentro del plazo autorizado, sin embargo también se permite la conclusión mediante la exportación definitiva de la mercancía dentro del plazo autorizado, para lo cual se deberá cumplir con las formalidades establecidas en el Reglamento.

\section{Regímenes de perfeccionamiento}

\subsection{De la admisión temporal para perfeccionamiento activo}

TÍTULO IV
REGÍMENES DE PERFECCIONAMIENTO
CAPÍTULO I
De la admisión temporal para perfeccionamiento
activo
Artículo $68^{\circ}$ - Admisión temporal para perfecciona-
miento activo
Régimen aduanero que permite el ingreso al terri-
torio aduanero de ciertas mercancías extranjeras con
la suspensión del pago de los derechos arancelarios
y demás impuestos aplicables a la importación para
el consumo y recargos de corresponder, con el fin
de ser exportadas dentro de un plazo determinado,
luego de haber sido sometidas a una operación de
perfeccionamiento, bajo la forma de productos com-
pensadores.

CAPITULO VI
Regímenes de Perfeccionamiento
SECCION I
Admisión Temporal para Perfeccionamiento Acrivo
Artículo $70^{\circ}$ - Es el Régimen Aduanero que permite
el ingreso de ciertas mercancías extranjeras al terri-
torio aduanero con suspensión del pago de los dere-
chos arancelarios y demás impuestos que graven su
importación, para ser exportadas dentro de un plazo
determinado, luego de haber sufrido una transfor-
mación o elaboración, debiendo dichas mercancías
estar materialmente incorporadas en el producto ex-
portado.
portado. 
Las operaciones de perfeccionamiento activo son aquellas en las que se produce:

a) La transformación de las mercancías;

b) La elaboración de las mercancías, incluidos su montaje, ensamble y adaptación a otras mercancias; $y$,

c) La reparación de mercancías, incluidas su restauración o acondicionamiento.

Están comprendidos en este régimen, las empresas productoras de bienes intermedios sometidos a procesos de transformación que abastezcan localmente a empresas exportadoras productoras, así como los procesos de maquila de acuerdo a lo establecido en el Reglamento.

Artículo $69^{\circ}$.- Mercancías objeto del régimen Podrán ser objeto de este régimen las materias primas, insumos, productos intermedios, partes y piezas materialmente incorporados en el producto exportado (compensador), incluyéndose aquellas mercancías que son absorbidas por el producto a exportar en el proceso de producción; así como las mercancías que se someten al proceso de reparación, restauración o acondicionamiento. Asimismo podrán ser objeto de este régimen mercancías tales como catalizadores, aceleradores o ralentizadores que se utilizan en el proceso de producción y que se consumen al ser utilizados para obtener el producto exportado (compensador).

No podrán ser objeto de éste régimen las mercancías que intervengan en el proceso productivo de manera auxiliar, tales como lubricantes, combustibles o cualquier otra fuente energética, cuando su función sea la de generar calor o energía, así como los repuestos y útiles de recambio, cuando no están materialmente incorporados en el producto final y no son utilizados directamente en el producto a exportar; salvo que estas mercancías sean en sí mismas parte principal de un proceso productivo.
Asimismo, podrán someterse a este Régimen aquellas mercancías que se utilicen directamente en el proceso de producción, tales como catalizadores, aceleradores o ralentizadores, que se consumen durante dicho proceso.

Están comprendidos en este Régimen, las empresas productoras de bienes intermedios sometidos a procesos de transformación que abastezcan localmente a empresas exportadoras productoras, así como los procesos de maquila.

\section{CAPITULO VI \\ Regímenes de Perfeccionamiento \\ SECCION I}

Admisión Temporal para Perfeccionamiento Activo

Artículo $70^{\circ}$.- Es el Régimen Aduanero que permite el ingreso de ciertas mercancías extranjeras al territorio aduanero con suspensión del pago de los derechos arancelarios y demás impuestos que graven su importación, para ser exportadas dentro de un plazo determinado, luego de haber sufrido una transformación o elaboración, debiendo dichas mercancías estar materialmente incorporadas en cl producto exportado.

Asimismo, podrán someterse a este Régimen aquellas mercancías que se utilicen directamente en el proceso de producción, tales como catalizadores, aceleradores o ralentizadores, que se consumen durante dicho proceso.

Están comprendidos en este Régimen, las empresas productoras de bienes intermedios sometidos a procesos de transformación que abastezcan localmente a empresas exportadoras productoras, así como los procesos de maquila. $\left.{ }^{*}\right)$

Nota: Reglamento del TUO DS No 011-2005-EF Artículo $122^{\circ}$ - Podrán ser objeto de admisión temporal, las materias primas, insumos, productos intermedios, partes y piezas materialmente incorporados en el producto exportado, incluyéndose 


\begin{tabular}{|c|c|}
\hline & $\begin{array}{l}\text { aquellas mercancías que son absorbidas por el pro- } \\
\text { ducto a exportar en el proceso de producción. Asi- } \\
\text { mismo, podrán ser objeto de admisión temporal } \\
\text { mercancías tales como catalizadores, aceleradores o } \\
\text { ralentizadores que se utilizan en el proceso de pro- } \\
\text { ducción que se consumen al ser utilizados para obte- } \\
\text { ner cl producto exportado } \\
\text { No podrán ser objeto de admisión temporal las mer- } \\
\text { cancías que intervengan en el proceso productivo de } \\
\text { manera auxiliar, tales como lubricantes, combusti- } \\
\text { bles o cualquier otra fuente energética, cuando su } \\
\text { función sea la de generar calor o energía, los repues- } \\
\text { tos, útiles de recambio, por cuanto no están mate- } \\
\text { rialmente incorporados en el producto final y no son } \\
\text { utilizados directamente en la obtención del producto } \\
\text { a exportar. }\end{array}$ \\
\hline $\begin{array}{l}\text { Artículo } 70^{\circ} \text { - Plazo } \\
\text { La admisión temporal para perfeccionamiento ac- } \\
\text { tivo es automáticamente autorizada con la presen- } \\
\text { tación de la declaración y de la garantía con una } \\
\text { vigencia igual al plazo solicitado y por un plazo } \\
\text { máximo de veinticuatro }(24) \text { meses computado a } \\
\text { partir de la fecha del levante. Si el plazo fuese me- } \\
\text { nor, las prórrogas serán aprobadas automáticamen- } \\
\text { te, con la sola renovación de la garantía antes del } \\
\text { vencimiento del plazo otorgado y sin exceder el } \\
\text { plazo máximo. }\end{array}$ & $\begin{array}{l}\text { *Artículo } 71^{\circ} \text { - El Régimen de Admisión Temporal } \\
\text { será autorizado automáticamente por el plazo solici- } \\
\text { tado por el beneficiario, sin exceder de veinticuatro } \\
\text { (24) meses, con la presentación de la declaración y de } \\
\text { la garantía con una vigencia igual al plazo solicitado. } \\
\text { Si éste fuese menor, las prórrogas serán aprobadas } \\
\text { automáticamente, antes del vencimiento del plazo } \\
\text { otorgado, con la sola renovación de la garantía sin } \\
\text { exceder en total el plazo máximo. } \\
\text { Los solicitantes del Régimen de Admisión Temporal } \\
\text { deberán constituir garantía por una suma equivalen- } \\
\text { te a los Derechos Arancelarios e impuestos respectivo } \\
\text { y, cuando corresponda, a los derechos antidumping o } \\
\text { compensatorios, más un interés compensatorio sobre } \\
\text { dicha suma, igual al promedio diario de la TAMEX } \\
\text { por día, proyectado desde la fecha de numeración de } \\
\text { la declaración de admisión temporal hasta la fecha } \\
\text { de vencimiento del plazo del régimen, a fin de res- } \\
\text { ponder por la deuda tributaria aduanera existente al } \\
\text { momento de la nacionalización. }\end{array}$ \\
\hline & $\begin{array}{l}\text { Nota: Reglamento del TUO DS No } 011-2005 \text {-EF } \\
\text { Artículo } 121^{\circ} \text { - El plazo de la admisión temporal } \\
\text { se cuenta a partir de la fecha de la numeración de la } \\
\text { declaración. }\end{array}$ \\
\hline $\begin{array}{l}\text { Artículo } 71^{\circ} \text { - Garantía } \\
\text { Para autorizar el presente régimen se deberá cons- } \\
\text { tituir garantía a satisfacción de la SUNAT por }\end{array}$ & $\begin{array}{l}\text { Artículo } 73^{\circ},-\mathrm{La} \text { admisión temporal concluye cuan- } \\
\text { do el beneficiario, directamente o a través de terceros } \\
\text { y dentro del plazo autorizado, exporta los productos }\end{array}$ \\
\hline
\end{tabular}


una suma equivalente a los derechos arancelarios y demás tributos aplicables a la importación para el consumo y recargos de corresponder, más un interés compensatorio sobre dicha suma, igual al promedio diario de la TAMEX por día proyectado desde la fecha de numeración de la declaración hasta la fecha de vencimiento del plazo del régimen, a fin de responder por la deuda existente al momento de la nacionalización. compensadores o cuando son ingresados a una zona franca, depósito franco o a los CETICOS.

Asimismo, concluye automáticamente por la ocurrencia de los siguientes supuestos:

a) La reexportación de las mercancías admitidas temporalmente o contenidas en excedentes con valor comercial;

b) El pago de los tributos y los derechos antidumping o compensatorios, más el interés compensatorio igual al promedio diario de la TAMEX por día, computado a partir de la fecha de numeración de la declaración de admisión temporal hasta la fecha de pago; en cuyo caso se dará por nacionalizadas las mercancías como tales, contenidas en productos compensadores y/o en excedentes con valor comercial. La SUNAT establecerá la formalidad y el procedimiento para la conclusión del régimen.

El interés compensatorio no será aplicable en la nacionalización de mercancías contenidas en excedentes con valor comercial.

En el caso de los productos compensadores y de los excedentes con valor comercial, el monto de los tributos aplicables estará limitado al de las mercancías admitidas temporalmente;

c) La destrucción total o parcial de la mercancía en caso fortuito, fuerza mayor o a solicitud del beneficiario, debidamente acreditada y aceptada ante la autoridad aduanera conforme lo establece el Reglamento.
Artículo $72^{\circ}$ - Buen contribuyente de la admisión temporal para reexportación en el mismo estado Las personas naturales o jurídicas podrán garantizar sus obligaciones en la forma y modo que se establezca mediante Decreto Supremo refrendado por el Ministro de Economía y Finanzas.

Artículo $73^{\circ}$.- Conclusión del régimen

El presente régimen concluye con:

a) La exportación de los productos compensadores o con su ingreso a una zona franca, depósito franco o a los CETICOS, efectuada por el beneficiario directamente o a través de terceros y dentro del plazo autorizado;
Artículo $73^{\circ}$.- La admisión temporal concluye cuando el beneficiario, directamente o a través de terceros y dentro del plazo autorizado, exporta los productos compensadores o cuando son ingresados a una zona franca, depósito franco o a los CETICOS. 
b) La reexportación de las mercancías admitidas temporalmente o contenidas en excedentes con valor comercial;

c) El pago de los derechos arancelarios y demás tributos aplicables y recargos de corresponder, más el interés compensatorio igual al promedio diario de la TAMEX por día, computado a partir de la fecha de numeración de la declaración hasta la fecha de pago, conforme a lo establecido por la Administración Aduanera; en cuyo caso se dará por nacionalizada la mercancía tales como las contenidas en productos compensadores $y / 0$ en excedentes con valor comercial. La Administración Aduanera establecerá la formalidad y el procedimiento para la conclusión del régimen.

El interés compensatorio no será aplicable en la nacionalización de mercancias contenidas en excedentes con valor comercial.

En el caso de los productos compensadores y de los excedentes con valor comercial, el monto de los tributos aplicables estará limitado al de las mercancías admitidas temporalmente;

d) La destrucción total o parcial de la mercancía por caso fortuito o fuerza mayor debidamente acreditada, o a solicitud del beneficiario la cual debe ser previamente aceptada por la autoridad aduanera conforme a lo establecido en el Reglamento.

$\mathrm{Si}$ al vencimiento del plazo autorizado no se hubiera concluido con el régimen de acuerdo a lo señalado en el párrafo precedente, la SUNAT automáticamente dará por nacionalizada la mercancía, por concluido el régimen, y ejecutará la garantía.

Artículo $74^{\circ}$.- Base imponible aplicable a los saldos Los derechos arancelarios y demás impuestos aplicables a la importación para el consumo y recargos de corresponder, aplicables a la importación para el consumo de los saldos pendientes, se calculan en función de la base imponible determinada en la declaración de admisión temporal para perfeccionamiento activo.

Artículo $75^{\circ}$.- Transferencia

Las mercancías admitidas temporalmente para perfeccionamiento activo y los bienes intermedios elaborados con mercancías admitidas temporalmente
Asimismo, concluye automáticamente por la ocurrencia de los siguientes supuestos:

a) La reexportación de las mercancías admitidas temporalmente o contenidas en excedentes con valor comercial;

b) El pago de los tributos y los derechos antidumping o compensatorios, más el interés compensatorio igual al promedio diario de la TAMEX por día, computado a partir de la fecha de numeración de la declaración de admisión temporal hasta la fecha de pago; en cuyo caso se dará por nacionalizadas las mercancías como tales, contenidas en productos compensadores y/o en excedentes con valor comercial. La SUNAT establecerá la formalidad y el procedimiento para la conclusión del régimen.

El interés compensatorio no será aplicable en la nacionalización de mercancías contenidas en excedentes con valor comercial.

En el caso de los productos compensadores y de los excedentes con valor comercial, el monto de los tributos aplicables estará limitado al de las mercancías admitidas temporalmente;

c) La destrucción total o parcial de la mercancía en caso fortuito, fuerza mayor o a solicitud del beneficiario, debidamente acreditada y aceptada ante la autoridad aduanera conforme lo establece el Reglamento.
Artículo $75^{\circ}$.- $\mathrm{Si}$ al vencimiento del plazo autorizado no se hubiera concluido con el régimen en la forma prevista en el artículo $73^{\circ}$ de la presente Ley, la autoridad aduanera dará por nacionalizada automáticamente la mercancía y concluido el régimen 
podrán ser objeto por una sola vez de transferencia automática a favor de terceros bajo cualquier título, de acuerdo a lo establecido en el Reglamento. de admisión temporal, ejecutándose la garantía conforme a lo establecido en el artículo $71^{\circ}$ de la presente Ley.

Artículo $74^{\circ}$ - Las mercancías admitidas temporalmente podrán ser objeto por una sola vez de transferencia automática a favor de terceros bajo cualquier título, de acuerdo a lo que señale el reglamento.

Con la nueva ley, se ha precisado cuáles son las operaciones con las que se produce el perfeccionamiento activo, siendo las siguientes: a) La transformación de las mercancías; b) la elaboración de las mercancías, incluidos su montaje, ensamble y adaptación a otras mercancías, y c) la reparación de mercancías, incluidas su restauración o acondicionamiento.

La ley derogada se refería solamente a la transformación o elaboración; con la nueva ley, se señala expresamente que también se refiere a la reparación de mercancías, incluidas su restauración o acondicionamiento. En este régimen, al igual que en el régimen de Admisión Temporal para Reexportación en el mismo Estado, se ha modificado la forma de cómputo de plazo, ya que los 24 meses se computan desde la fecha del levante y no desde la numeración de la declaración.

\subsection{De la exportación temporal para perfeccionamiento pasivo}

\begin{tabular}{|c|c|}
\hline & \\
\hline CAPÍTULO II & CAPITULO V \\
\hline De la exportación temporal para perfecciona- & Regímenes Temporales \\
\hline miento pasivo & $(\ldots)$ \\
\hline $\begin{array}{l}\text { Artículo } 76^{\circ} \text { - Exportación temporal para perfec- } \\
\text { cionamiento pasivo }\end{array}$ & SECCION II \\
\hline $\begin{array}{l}\text { Régimen aduanero mediante el cual se permite la } \\
\text { salida temporal del territorio aduanero de mercan- } \\
\text { ćas nacionales o nacionalizadas para su transfor- } \\
\text { mación, elaboración o reparación y luego reimpor- } \\
\text { tarlas como productos compensadores en un plazo } \\
\text { determinado. }\end{array}$ & $\begin{array}{l}\text { Artículo } 66^{\circ} \text {.- Se considerará como una expor- } \\
\text { tación temporal el cambio o reparación de mer- } \\
\text { cancías que, habiendo sido declaradas y naciona- } \\
\text { lizadas, resulten deficientes o no corresponda a la } \\
\text { solicitada por el importador, siempre y cuando di- } \\
\text { cha exportación se efectúe dentro de los } 12 \text { (doce) }\end{array}$ \\
\hline $\begin{array}{l}\text { Las operaciones de perfeccionamiento pasivo son } \\
\text { aquellas en las que se produce: }\end{array}$ & meses contados a partir de la numeración de la \\
\hline
\end{tabular}


a) La transformación de las mercancías;

b) La elaboración de las mercancías, incluidos su montaje, ensamble o adaptación a otras mercancías; $y$,

c) La reparación de mercancías, incluidas su restauración o acondicionamiento. declaración de importación y previa presentación de la documentación sustentatoria.

Tratándose de mercancías nacionalizadas que han sido objeto de reconocimiento físico, cuya garantía comercial no exija su devolución, el dueño o consignatario podrá solicitar su destrucción bajo su costo y riesgo a fin que sea sustituida por otra idéntica o similar, según las disposiciones que establezca la SUNAT.

Artículo $69^{\circ}$.- Cuando las mercancías exportadas temporalmente se reimporten, después de ser reparadas o perfeccionadas en el exterior, la determinación de la base imponible para el cobro de los derechos arancelarios y demás tributos se calculará sobre el monto del valor agregado.

Artículo $77^{\circ}$.- Plazo
La reimportación de los productos compensadores deberá realizarse dentro de un plazo máximo de doce (12) meses contado a partir de la fecha del término del embarque de las mercancías exportadas temporalmente para perfeccionamiento pasivo.

El plazo señalado en el párrafo anterior podrá ser ampliado por la Administración Aduanera en casos debidamente justificados por el beneficiario.

Artículo $65^{\circ}$.- Es el Régimen Aduanero que permite la salida temporal al exterior de mercancías nacionales o nacionalizadas con la obligación de reimportarlas en un plazo determinado, en el mismo estado o luego de haber sido sometidas a una reparación, cambio o mejoramiento de sus características.

El plazo de la exportación temporal será automáticamente concedido por doce (12) meses, computados a partir de la fecha del término del embarque de la mercancía, dentro del cual deberá efectuarse la reimportación.

El plazo señalado en el párrafo anterior podrá ser ampliado por ADUANAS, a solicitud del interesado, en casos debidamente justificados. Vencido el plazo de exportación temporal, o el de la prórroga en su caso, la mercancía se considerará automáticamente exportada en forma definitiva.

Artículo $78^{\circ}$.- Cambio o reparación de mercancía deficiente o no solicitada

Se considerará como una exportación temporal para perfeccionamiento pasivo el cambio o repara-
Artículo $66^{\circ}\left({ }^{*}\right)\left({ }^{* *}\right)$.- Se considerará como una exportación temporal el cambio o reparación de mercancías que, habiendo sido declaradas y nacionalizadas, resulten deficientes o no corresponda 
ción de la mercancía que, habiendo sido declarada y nacionalizada, resulte deficiente o no corresponda a la solicitada por el importador, siempre y cuando dicha exportación se efectúe dentro de los doce (12) meses contados a partir de la numeración de la declaración de importación para el consumo y previa presentación de la documentación sustentatoria. Tratándose de mercancía nacionalizada que ha sido objeto de reconocimiento físico, cuya garantía comercial no exija su devolución, el dueño o consignatario podrá solicitar su destrucción bajo su costo y riesgo a fin de que sea sustituida por otra idéntica o similar, según las disposiciones que establezca la Administración Aduanera.

Artículo $79^{\circ}$.- Conclusión

El régimen concluye con la reimportación de la mercancia por el beneficiario, en uno o varios envíos y, dentro del plazo autorizado.

Se podrá solicitar la exportación definitiva de la mercancía dentro del plazo autorizado, para lo cual se deberá cumplir con lo establecido en el Reglamento, con lo que se dará por regularizado el régimen.

Artículo $80^{\circ}$.- Determinación de la base imponible Cuando las mercancías exportadas temporalmente se reimporten, después de ser reparadas, cambiadas o perfeccionadas en el exterior, la determinación de la base imponible para el cobro de los derechos arancelarios y demás tributos aplicables a la importación para el consumo y recargos de corresponder, se calculará sobre el monto del valor agregado o sobre la diferencia por el mayor valor producto del cambio, más los gastos de transporte y seguro ocasionados por la salida y retorno de la mercancía, de corresponder. la solicitada por el importador, siempre y cuando dicha exportación se efecrúe dentro de los 12 (doce) meses contados a partir de la numeración de la declaración de importación y previa presentación de la documentación sustentatoria.

Tratándose de mercancias nacionalizadas que han sido objeto de reconocimiento físico, cuya garantía comercial no exija su devolución, el dueño o consignatario podrá solicitar su destrucción bajo su costo y riesgo a fin que sea sustituida por otra idéntica o similar, según las disposiciones que establezca la SUNAT.

(*) Artículo sustituido por el artículo $39^{\circ}$ del Decreto Legislativo No 951, publicado el 3 de febrero de 2004 (**) Artículo modificado por Ley No 29176, publicada el 03.01.2008

${ }^{(* *)}$ Fe de Erratas, publicado el 09.01.2008
Artículo $69^{\circ}$.- Cuando las mercancías exportadas temporalmente se reimporten, después de ser reparadas o perfeccionadas en el exterior, la determinación de la base imponible para el cobro de los derechos arancelarios y demás tributos se calculará sobre el monto del valor agregado. 
Artículo $81^{\circ}$.- Reparación o cambio de la mercancía efectuada en forma gratuita.

Cuando la operación de perfeccionamiento pasivo tenga por objeto la reparación o el cambio de la mercancía por otra equivalente, efectuada de forma gratuita y por motivos de obligación contractual o legal de garantía, acreditada ante las autoridades aduaneras, en la reimportación la determinación de la base imponible para el cobro de los derechos arancelarios y demás tributos aplicables a la importación para el consumo y recargos de corresponder, se calculará únicamente sobre el monto de los gastos de transporte y seguro ocasionados por la salida y retorno de la mercancía, salvo que la mercancía objeto del cambio sea de mayor valor en cuyo caso esta diferencia en el valor formará parte de la base imponible, siempre y cuando la exportación temporal se efectúe dentro de los doce (12) meses contados a partir de la numeración de la declaración de importación para el consumo.

No procede la devolución de tributos en caso que el cambio se realice por mercancía de menor valor.
Nota: Reglamento del TUO DS No 011-2005-EF Artículo $116^{\circ}$.- A efectos de la determinación de la deuda tributaria aduanera en el caso contemplado en el artículo $69^{\circ}$ de la Ley, el valor agregado está compuesto por el valor de la reparación o perfeccionamiento de la mercancía en el exterior y los gastos de transporte y de seguro ocasionados por la salida y retorno de la mercancía.

Nota: Reglamento del TUO DS No 011-2005-EF Artículo $116^{\circ}$.- A efectos de la determinación de la deuda tributaria aduanera en el caso contemplado en el artículo $69^{\circ}$ de la Ley, el valor agregado está compuesto por el valor de la reparación o perfeccionamiento de la mercancía en el exterior y los gastos de transporte y de seguro ocasionados por la salida y retorno de la mercancía.

Este régimen hace suyo uno de los supuestos que contemplaba el régimen de exportación temporal de la ley anterior, es el régimen contrario al de admisión temporal para perfeccionamiento activo, permite la salida temporal del territorio aduanero de mercancías nacionales o nacionalizadas para su transformación, elaboración o reparación y luego reimportarlas como productos compensadores en un plazo máximo de doce (12) meses contado a partir de la fecha del término del embarque.

Se precisa que el perfeccionamiento pasivo consiste en: a) La transformación de las mercancías, b) la elaboración de las mercancías, incluidos su montaje, ensamble o adaptación a otras mercancías; y, c) la reparación de mercancías, incluidas su restauración o acondicionamiento.

Se señala que el cálculo de la base imponible para el cobro de los derechos arancelarios y demás tributos aplicables a la importación para el consumo y recargos de corresponder, se realizara sobre el monto del valor agregado o sobre la diferencia por el mayor valor producto del cambio más los gastos de transporte y seguro ocasionados por la salida y retorno de la mercancía de corresponder. La ley derogada solo señalaba que el cálculo se realizaba sobre el 
valor agregado, siendo complementada por el artículo $116^{\circ}$ de su reglamento, donde se señalaba que el valor agregado está compuesto por el valor de la reparación o perfeccionamiento de la mercancía en el exterior y los gastos de transporte y de seguro ocasionados por la salida y retorno de la mercancía.

La nueva ley prevé que cuando la reparación o cambio de la mercancía es efectuada en forma gratuita y por motivos de obligación contractual o legal de garantía, acreditada ante las autoridades aduaneras, el cálculo de la base imponible para el cobro de los derechos arancelarios y demás tributos aplicables a la importación para el consumo y recargos de corresponder se calculará únicamente sobre el monto de los gastos de transporte y seguro ocasionados por la salida y retorno de la mercancía; salvo que la mercancía objeto del cambio sea de mayor valor, en cuyo caso esta diferencia en el valor formará parte de la base imponible, siempre y cuando la exportación temporal se efectúe dentro de los doce (12) meses contados a partir de la numeración de la declaración de importación para el consumo. Asimismo, precisa que no procede la devolución de tributos en caso que el cambio se realice por mercancía de menor valor.

El artículo $78^{\circ}$ de la nueva Ley recoge la modificatoria establecida por la Ley № 29176 -Ley de Simplificación Aduanera-, al establecer como plazo para materializar el cambio o recambio de mercancías defectuosas, doce (12) meses, plazo que sustituyó a los tres (03) meses previstos antes de la mencionada modificatoria. Esto surgió como una necesidad de adecuarse a los plazos que normalmente las garantías comerciales emitidas por los proveedores contemplan, permitiendo de esta manera que la práctica aduanera resulte acorde a la realidad comercial imperante.

5.3. Drawback

\section{CAPITULO III \\ Del drawback}

Artículo $82^{\circ}$.- Drawback

Régimen aduanero que permite, como consecuencia de la exportación de mercancías, obtener la restitución total o parcial de los derechos arancelarios, que hayan gravado la importación para el consumo de las mercancías contenidas en los bienes exportados o consumidos durante su producción.

\section{SECCION II \\ Drawback}

Artículo $76^{\circ}$.- Es el Régimen Aduanero que permite, como consecuencia de la exportación de mercancías, obtener la restitución total o parcial de los derechos arancelarios, que hayan gravado la importación de las mercancías contenidas en los bienes exportados o consumidos durante su producción.
Artículo $83^{\circ}$.- Procedimientos simplificados de restitución arancelaria

Por Decreto Supremo refrendado por el Ministro de Economía y Finanzas se podrán establecer los procedimientos simplificados de restitución arancelaria.
Artículo $77^{\circ}$.- Por Decreto Supremo se podrán establecer Procedimientos Simplificados de Restitución Arancelaria. 
Como se observa, respecto a este régimen no existe variación, dejándose su regulación conforme al artículo $83^{\circ}$, a la norma especial, en este caso Decreto Supremo No 104-95-EF Reglamento de procedimiento de restitución simplificado de derechos arancelarios.

\subsection{De la reposición de mercancías con franquicia arancelaria}

\begin{tabular}{|c|c|}
\hline $\begin{array}{c}\text { CAPÍTULO IV } \\
\text { De la reposición de mercancías con franquicia } \\
\text { arancelaria }\end{array}$ & $\begin{array}{c}\text { SECCION III } \\
\text { Reposición de Mercancías en Franquicia }\end{array}$ \\
\hline $\begin{array}{l}\text { Artículo } 84^{\circ} \text { - Reposición de mercancías con fran- } \\
\text { quicia arancelaria } \\
\text { Régimen aduanero que permite la importación } \\
\text { para el consumo de mercancías equivalentes, a las } \\
\text { que habiendo sido nacionalizadas, han sido utili- } \\
\text { zadas para obtener las mercancías exportadas pre- } \\
\text { viamente con carácter definitivo, sin el pago de los } \\
\text { derechos arancelarios y demás impuestos aplicables } \\
\text { a la importación para el consumo. } \\
\text { Son beneficiarios del régimen los importadores } \\
\text { productores y los exportadores productores que ha- } \\
\text { yan importado por cuenta propia los bienes sujetos } \\
\text { a reposición de mercancía en franquicia. } \\
\text { Artículo } 85^{\circ} \text { - Mercancías objeto del régimen } \\
\text { Podrán ser objeto de éste régimen toda mercancía } \\
\text { que es sometida a un proceso de transformación } \\
\text { o elaboración, que se hubiere incorporado en un } \\
\text { producto de exportación o consumido al participar } \\
\text { directamente durante su proceso productivo. } \\
\text { No podrán ser objeto de este régimen las mercan- } \\
\text { cías que intervengan en el proceso productivo de } \\
\text { manera auxiliar, tales como lubricantes, combusti- } \\
\text { bles o cualquier otra fuente energética, cuando su } \\
\text { función sea la de generar calor o energía; los re- } \\
\text { puestos y útiles de recambio, cuando no están ma- } \\
\text { terialmente incorporados en el producto final y no } \\
\text { son utilizados directamente en el producto a expor- } \\
\text { tar; salvo que estas mercancías sean en sí mismas } \\
\text { parte principal de un proceso productivo. } \\
\text { Artículo } 86^{\circ} \text { - Plazos } \\
\text { Para acogerse a este régimen, la declaración de ex- } \\
\text { portación debe presentarse en el plazo de un (1) }\end{array}$ & $\begin{array}{l}\text { Artículo } 79^{\circ} \text { - Para acogerse al Régimen de Reposi- } \\
\text { ción de Mercancías en Franquicia, la Declaración de } \\
\text { Exportación deberá presentarse en el plazo de un (1) } \\
\text { año, contado a partir de la fecha de numeración de } \\
\text { la Declaración de Importación que sustente el ingre- } \\
\text { so de la mercancía a reponer. } \\
\text { La importación de mercancías en franquicia deberá } \\
\text { efectuarse en el plazo de un (1) año, contado a partir } \\
\text { de la fecha de emisión del Certificado de Reposi- } \\
\text { ción. } \\
\text { Podrán realizarse despachos parciales siempre que se } \\
\text { realicen dentro de dicho plazo. } \\
\text { Artículo } 80^{\circ} \text {.- Las mercancías importadas bajo repo- } \\
\text { sición son de libre disponibilidad. Sin embargo, en } \\
\text { el caso que éstas se exporten, podrán ser objeto de } \\
\text { nuevo beneficio. }\end{array}$ \\
\hline
\end{tabular}


año, contado a partir de la fecha de levante de la declaración de importación para el consumo que sustente el ingreso de la mercancía a reponer. La importación para el consumo de mercancías en franquicia deberá efectuarse en el plazo de un (1) año, contado a partir de la fecha de emisión del cerrificado de reposición.

Podrán realizarse despachos parciales siempre que se realicen dentro de dicho plazo

Artículo $87^{\circ}$.- Libre disponibilidad de las mercancías

Las mercancías importadas bajo este régimen son de libre disponibilidad. Sin embargo, en el caso que éstas se exporten, podrán ser objero de nuevo beneficio.
Nota: Reglamento del TUO DS No 011-2005-EF SECCIÓN III

Reposición de Mercancías en Franquicia Artículo 132.- Mediante el régimen de reposición de mercancías en franquicia, las personas naturales o jurídicas que hubieren exportado, directamente o a través de terceros, productos en los que se han utilizado mercancías importadas, tendrán derecho a la obtención del certificado de reposición, el mismo que es transferible por simple endoso.

Puede ser objeto de reposición, toda mercancía que es sometida a un proceso de transformación o elaboración que se hubiere incorporado en un producto de exportación o se hubiere consumido al participar directamente durante su proceso productivo.

No puede ser objeto de reposición las mercancías que intervengan de manera auxiliar en el proceso productivo, tales como el combustible o cualquier otra fuente energética, cuando su función fuere generar calor o energía para la obtención del producto exportado. Tampoco se consideran los repuestos y los útiles de recambio que se consuman o empleen en la obtención de estos bienes.

La nueva ley señala qué mercancías no pueden ser objeto de este régimen, la norma anterior no lo señalaba, dejando ello a su reglamento. En cuanto al plazo, señala que para acogerse a este régimen, la declaración de exportación debe presentarse en el plazo de un (1) año, contado a partir de la fecha de levante de la declaración de importación para el consumo que sustente el ingreso de la mercancía a reponer. La anterior norma establecía también el plazo de un (1) año, pero contado a partir de la fecha de numeración de la declaración de importación que sustentaba el ingreso de la mercancía a reponer. 


\begin{tabular}{|c|c|}
\hline 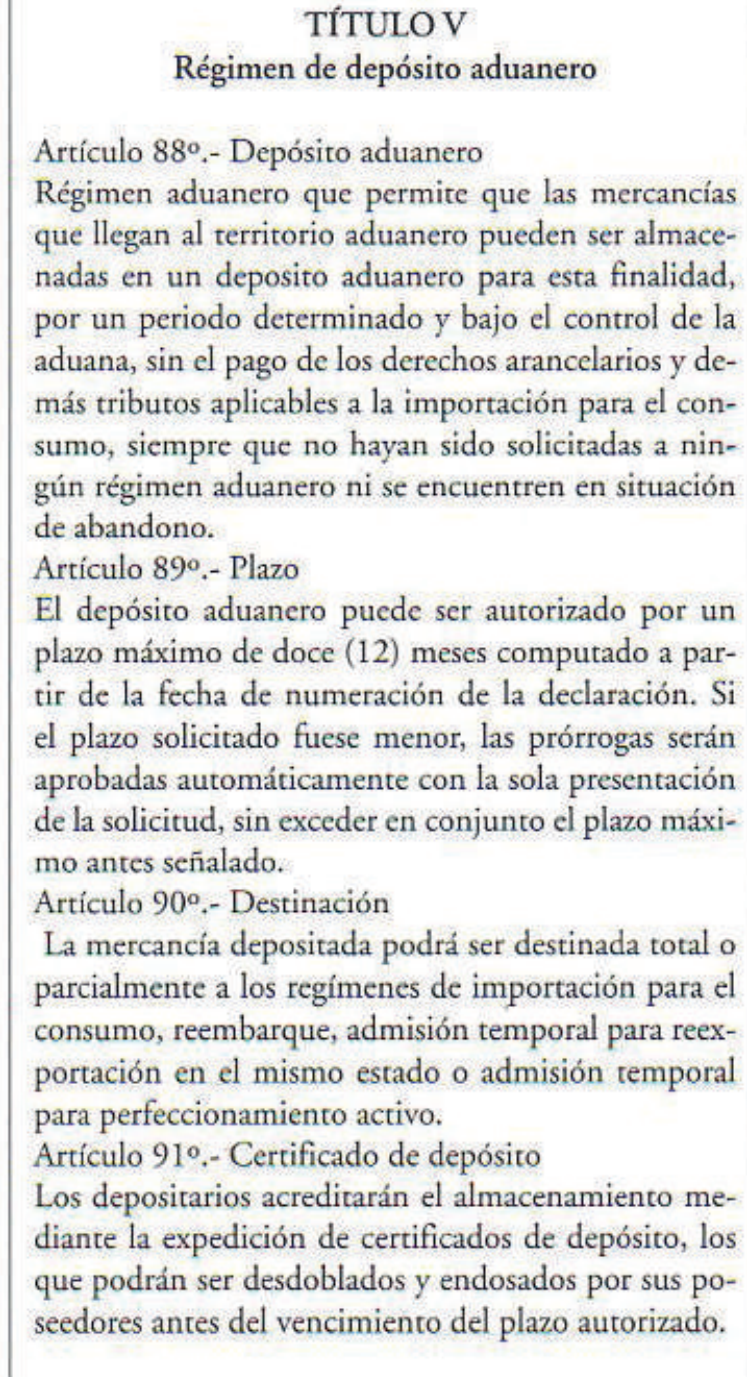 & $\begin{array}{l}\text { Artículo } 60^{\circ} \text {. Es el Régimen Aduanero, que per- } \\
\text { mite almacenar las mercancías que llegan al territo-- } \\
\text { rio aduanero bajo control de la Aduana, en lugares } \\
\text { autorizados, sin el pago de los derechos arancela- } \\
\text { rios y demás impuestos que gravan la importación, } \\
\text { siempre que no hayan sido solicitadas a ningún ré- } \\
\text { gimen aduanero ni se encuentren en situación de } \\
\text { abandono. } \\
\text { El plazo del depósito será el que fije el interesado } \\
\text { en su solicitud, la misma que será aprobada auto- } \\
\text { máticamente por el solo mérito de su presentación, } \\
\text { no debiendo exceder dicho plazo de doce (12) me- } \\
\text { ses. Si el plazo solicitado fuese menor, las prórrogas } \\
\text { serán aprobadas automáticamente con la sola pre- } \\
\text { sentación de la solicitud, sin exceder en conjunto } \\
\text { el plazo máximo antes señalado. }\left({ }^{*}\right)\end{array}$ \\
\hline
\end{tabular}

Este régimen no ha sufrido cambios, sin embargo cabe señalar que, en cuanto a su ubicación, la norma anterior lo clasificaba dentro de los denominados regímenes suspensivos, la nueva ley lo trata como un régimen independiente. 


\section{Regímenes de tránsito}

\subsection{Del tránsito aduanero}

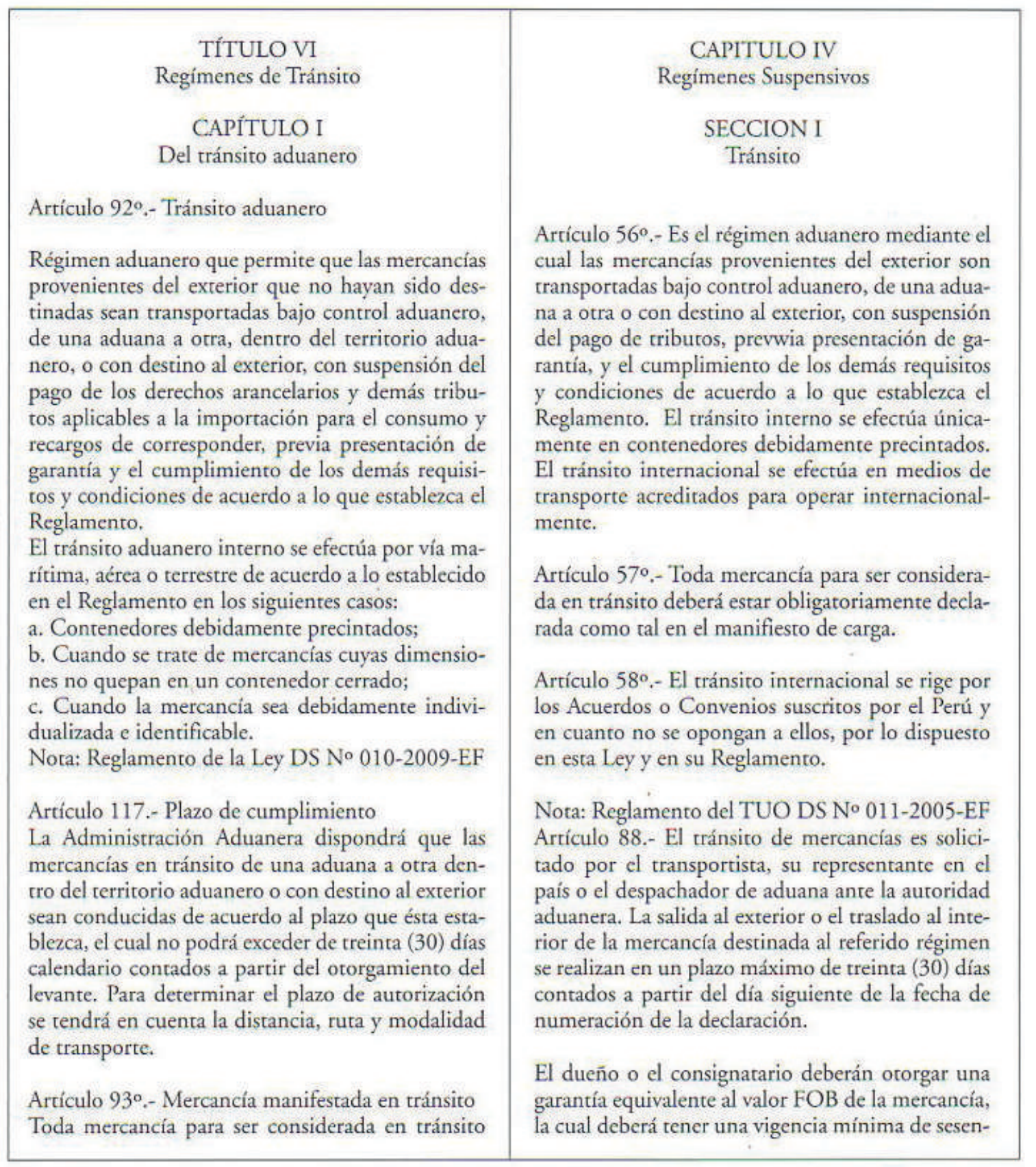


deberá estar obligatoriamente declarada como tal en el manifiesto de carga.

Artículo 94\%.- Tránsito aduanero internacional El tránsito internacional se efectúa en medios de transporte acreditados para operar internacionalmente $\mathrm{y}$ se rige por los tratados o convenios suscritos por el Perú y en cuanto no se opongan a ellos, por lo dispuesto en este Decreto Legislativo y su Reglamento. ta $(60)$ días calendario contados desde la fecha de presentación de la solicitud, a fin de garantizar el traslado de la mercancía y el cumplimiento de las demás obligaciones establecidas para el régimen. La garantía la presenta el declarante en el momento de solicitar la destinación.

El declarante es responsable de la salida del territorio aduanero o de la entrega de las mercancías al almacén aduanero en la aduana del interior y del cumplimiento de las demás obligaciones que el régimen le impone.

La autoridad aduanera dispondrá que las mercancías en tránsito terrestre de una aduana a otra dentro del territorio aduanero sean conducidas de acuerdo al plazo que ésta establezca. Para determinar el plazo de autorización se tendrá en cuenta la distancia y podrá prorrogarse excepcionalmente por única vez, a solicitud del interesado, en los casos debidamente justificados.

El tránsito interno terrestre de mercancías involucra una aduana de ingreso y una aduana del interior.

La nueva ley ha mantenido la figura del tránsito interno, que fue reincorporada a nuestra legislación mediante la Ley No 28977 - Ley de facilitación del comercio exterior ${ }^{4}$ En cuanto al plazo establecido para llevar a cabo la salida de la mercancía del país en el régimen de tránsito, debe indicarse que el reglamento actual ha precisado que el plazo de treinta (30) días para que se culmine con la operación, son días calendarios; así también para el otorgamiento del plazo se han ampliado los criterios que la administración tiene para poder otorgarlo (como son la ruta y la modalidad empleada), ya que el anterior reglamento sólo contemplaba el criterio de la distancia. La nueva ley contempla el tránsito de una aduana a otra, dentro del territorio aduanero (tránsito interno), así también el tránsito con destino al exterior.

4 El Artículo 11 de la Ley 28977.- Promoción de puertos interiores del país, señalo lo siguiente. Modificase el artículo 56 de la Ley General de Aduanas, Decreto Legislativo No 809 y sus modificatorias, con el siguiente texto:

"Articulo 56. - Es el régimen aduanero mediante el cual las mercancias provenientes del exterior son transportadas bajo control aduanero, de una aduana a otra o con destino al exterior, con suspensión del pago de tributos, previa presentación de garantia, y el cumplimiento de los demás requisitos y condiciones de acuerdo a lo que establezca el Reglamento. El tránsito interno se efectia tinicamente en contenedores debidamente precintados. El transito internacional se efectia en medios de transporte acreditados para operar internacionalmente". 
El tránsito interno se encontraba previsto en la Ley General de Aduanas aprobada por el Decreto Legislativo No 722 y que fuera modificada por el Decreto Legislativo № 778 , por medio del cual se retiro dicha figura, situación que se mantuvo posteriormente con la dación de la Ley General de Aduanas aprobada por Decreto Legislativo № 809, hasta que fue modificada por la Ley № 28977 señalada, reincorporándose el tránsito interno.

La nueva ley precisa que el tránsito aduanero interno se efectúa por vía marítima, aérea o terrestre, en los siguientes casos: a) Contenedores debidamente precintados, b) cuando se trate de mercancías cuyas dimensiones no quepan en un contenedor cerrado, y c) cuando la mercancía sea debidamente individualizada e identificable, la norma anterior solo señalaba que el tránsito interno se efectúa únicamente en contenedores debidamente precintados.

Cabe señalar al respecto, que el retiro de nuestra legislación aduanera de la figura del tránsito interno trajo como consecuencia problemas para la aplicación de los beneficios del Convenio de Cooperación Aduanera Peruano Colombiano (PECO), por lo que se promulgó el Decreto Supremo No 15-94-EF, que estableció el procedimiento operativo para el ingreso de las mercancías a la zona del PECO, una especie de tránsito interno pero aplicable solo para este caso en concreto.

En ese sentido, surge la inquietud de que con la nueva ley que contempla el tránsito interno, se podría dejar de aplicar el Decreto Supremo No 15-94-EF, a fin de ingresar las mercancías a la zona del PECO, sin embargo conforme está regulado, en la nueva ley, todavía existe una ventaja al aplicar el Decreto Supremo señalado, ya que mediante este procedimiento el pago en la aduana de ingreso es sobre el monto de los tributos, en cambio con el tránsito interno el pago o afianzamiento que se realice en la aduana donde se numere la declaración aduanera de tránsito es sobre el valor FOB de la mercancías, evidentemente un monto mayor.

5 "Articulo 145.- Mercancia declarada y encontrada

Los derechos arancelarios y demás impuestos se aplican respecto de la mercancia consignada en la declaración aduanera y, en caso de reconocimiento fisico, sobre la mercancía encontrada, siempre que ésta sea menor a la declarada. En caso que la mercancia encontrada por el dueño o consignatario con posterioridad al levante fuese mayor a la consignada en la declaración aduanera, a opción del importador, ésta podrá ser declarada sin ser sujeta a sanción y con el sólo pago de la desida tributaria aduanera y los recargos que correspondan, o podrá ser reembarcada. La destinación al régimen de reembarque solo procederá dentro del plazo de treinta (30) dias computados a partir de la fecha del retiro de la mercancia. Si la Autoridad Aduanera, durante el reconocimiento fisico, encontrana mercancía no declarada, ésta caerá en comiso o a opción del importador, podrá ser reembarcada previo pago de una multa y siempre que el reembarque se realice dentro del plazo de treinta (30) dias computados a partir de la fecha del reconocimiento fisico de la mercancia". 


\subsection{Del Transbordo}

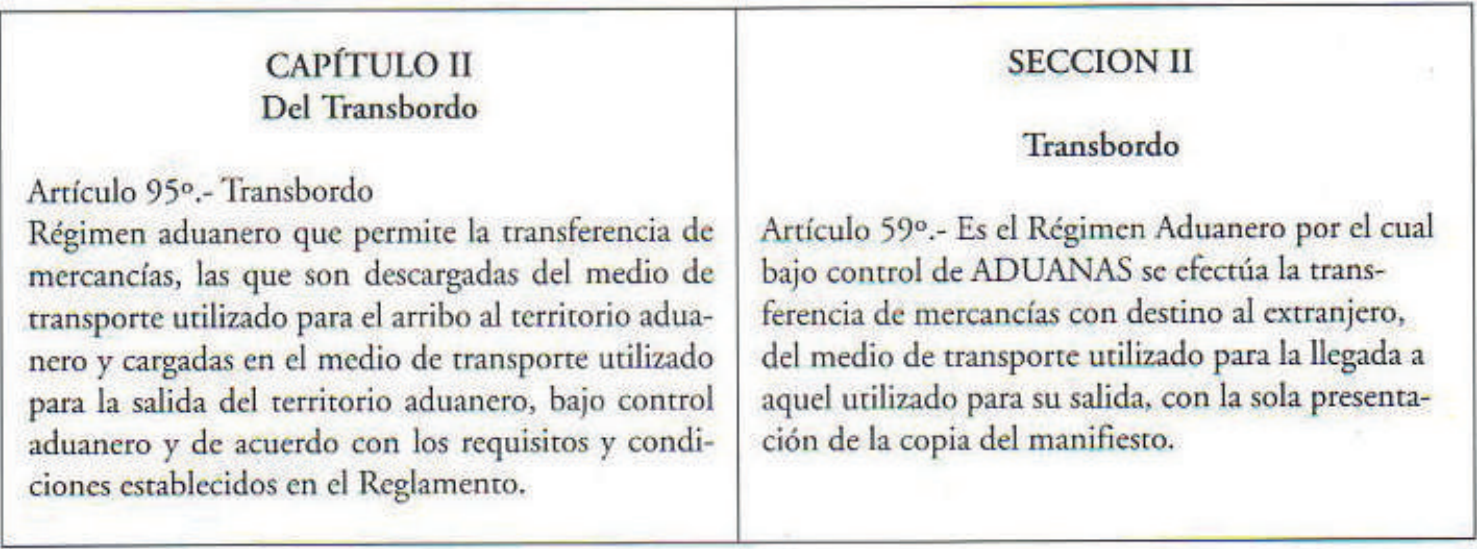

No se han producido cambios importantes al respecto, sin embargo debemos señalar que el régimen de tránsito con la nueva ley está dentro de los regímenes denominados de tránsito, con la anterior ley se ubicaban en los regímenes suspensivos.

\subsection{Del Reembarque}

\section{CAPÍTULO III \\ Del Reembarque}

Artículo $96^{\circ}$-- Reembarque

Régimen aduanero que permite que las mercancías que se encuentran en un punto de llegada en espera de la asignación de un régimen aduanero puedan ser reembarcadas desde el territorio aduanero con destino al exterior, siempre que no se encuentren en situación de abandono.

$\mathrm{La}$ autoridad aduanera podrá disponer de oficio el reembarque de una mercancía de acuerdo a lo establecido en el Reglamento.

Artículo 97\%.- Excepciones

Por excepción será reembarcada, dentro del término que fije el Reglamento, la mercancía destinada a un régimen aduanero que, como consecuencia del reconocimiento físico, se constate lo siguiente:

a) Su importación se encuentre prohibida, salvo que por disposición legal se establezca otra medida;

b) Su importación se encuentre restringida y no

\section{CAPITULO VII \\ Operaciones Aduaneras \\ SECCION UNICA \\ Reembarque}

Artículo $81^{\circ}$.- Procede el reembarque de las mercancías, sólo con destino al exterior mientras no hayan sido solicitadas para uso o consumo o no se encuentren en situación de abandono.

Artículo $82^{\circ}$.- Por excepción será reembarcada, dentro del término que fije el Reglamento, la mercancía destinada aduaneramente que, como consecuencia del reconocimiento físico, se constate lo siguiente:

a) Su importación se encuentre prohibida, salvo que por disposición legal se establezca otra medida; b) Su importación se encuentre restringida y no cumpla con los requisitos establecidos para su in- 
cumpla con los requisitos establecidos para su ingreso al país. En ningún caso, la autoridad aduanera podrá disponer el reembarque de la mercancía cuando el usuario subsane el requisito incumplido, incluso en el supuesto en que tal subsanación se lleve a cabo durante el proceso de despacho;

c) Se encuentra deteriorada;

d) No cumpla con el fin para el que fue importada.

No procede bajo ninguna circunstancia el reembarque de mercancía no declarada, salvo lo previsto en el artículo $145^{\circ}$ del presente Decreto Legislativo.

Puede ser reembarcada la mercancía que se encuentre en un depósito aduanero. greso al país;

c) Se encuentra deteriorada;

d) No cumpla con el fin para el que fue importada.

No procede bajo ninguna circunstancia el reembarque de mercancía no declarada.

Con la nueva ley, el reembarque es denominado régimen aduanero y no, operación aduanera como lo señalaba la anterior ley.

El artículo $145^{\circ}$ de la nueva ley establece que cuando producto del reconocimiento físico se detecta mercancía no declarada, ésta caerá en comiso o a opción del importador, podrá ser reembarcada previo pago de una multa siempre que el reembarque se realice dentro del plazo de treinta (30) días computados a partir de la fecha del reconocimiento físico de la mercancía, por lo que en ciertos casos procederá el reembarque de mercancías que tengan la naturaleza jurídica de no declarada, situación que no se preveía con la norma anterior, pues estaba prohibido el reembarque de mercancías no declarada.

\section{Otros regímenes aduaneros o de excepción}

\begin{tabular}{|c|c|}
\hline $\begin{array}{l}\text { TÍTULO VII } \\
\text { Otros Regímenes Aduaneros o de Excepción } \\
\text { CAPÍTULO I } \\
\text { GENERALIDADES } \\
\text { Artículo } 98^{\circ} \text {.- Regímenes aduaneros especiales o de } \\
\text { excepción } \\
\text { Los regímenes aduaneros especiales o trámites } \\
\text { aduaneros especiales o de excepción que a conti- } \\
\text { nuación se señalan, se sujetan a las siguientes reglas: } \\
\text { a) El tráfico fronterizo se limita exclusivamente } \\
\text { a las zonas de intercambio de mercancías destina- } \\
\text { das al uso y consumo doméstico entre poblaciones }\end{array}$ & $\begin{array}{l}\text { CAPITULO VIII } \\
\text { Destinos Aduaneros Especiales o de Excepción } \\
\text { SECCION UNICA } \\
\text { Generalidades }\end{array}$ \\
\hline
\end{tabular}


fronterizas, en el marco de los convenios internacionales y la legislación nacional vigentes;

b) El tráfico de envíos o paquetes postales transportados por el servicio postal se rige por el Convenio Postal Universal y la legislación nacional vigente;

c) El ingreso o salida de envíos de entrega rápida transportados por empresas del servicio de entrega rápida, también denominados "courier"; se rige por su Reglamento;

d) El ingreso, salida y permanencia de vehículos para turismo se rige por las disposiciones del Convenio Internacional de Carné de Paso por Aduanas $y$ lo que señale el Reglamento;

e) El almacén libre (Duty Free) es el régimen especial que permite en los locales autorizados ubicados en los puertos o aeropuertos internacionales almacenar y vender mercancías nacionales o extranjeras, exentas del pago de tributos que las gravan, a los pasajeros que entran o salen del país o se encuentren en tránsito;

f) Las mercancías destinadas para el uso y consumo de los pasajeros y miembros de la tripulación a bordo de los medios de transporte de tráfico internacional, ya sean objeto de venta o no y las mercancías necesarias para el funcionamiento, conservación y mantenimiento de éstos, serán considerados como rancho de nave o provisiones de a bordo y se admitirán exentas del pago de derechos arancelarios y demás impuestos que gravan la importación para el consumo;

g) El material especial para la carga, descarga, manipulación y protección de las mercancías en el Tráfico Internacional Acuático o Terrestre que ingrese y esté destinado a reexportarse en el mismo transporte, así como los repuestos y accesorios necesarios para su reparación, podrán ingresar sin el pago de derechos arancelarios ni impuestos que gravan la importación para el consumo y sin la exigencia de presentación de garantía;

h) El material para uso aeronáutico destinado para la reparación o mantenimiento, los equipos para la recepción de pasajeros, manipuleo de la carga y demás mercancías necesarios para la operatividad de las acronaves nacionales o internacionales ingresa libre de derechos de aduana y demás tributos, siempre que se trate de materiales que no se internen al país y que permanezcan bajo control aduanero, dentro de los límites de las zonas que se señale en tados por el servicio postal o los concesionarios postales se rige por el Convenio Postal Universal. c) El ingreso o salida de mercancías contenidas en envíos o paquetes transportados por concesionarios postales, también denominados de mensajería internacional, correos rápidos o "courier", cuyo valor total CIF o FOB, según corresponda, no exceda los límites que señale su Reglamento, se despacharán por la aduana mediante formalidades simplificadas.

Los envíos o paquetes cuyo valor excedan del límite establecido, se sujetarán al trámite y formalidades generales.

El Reglamento determinará las formalidades aplicables a los concesionarios postales, en lo que respecta a su formalización, garantía y otras exigencias que aseguren la prestación eficiente del servicio.

d) El ingreso, salida y permanencia de vehículos para turismo se rige por las disposiciones del Convenio Internacional de Carné de Paso por Aduanas y lo que señale el Reglamento.

e) El Almacén Libre (Duty Frec) es el régimen especial que permite en los locales autorizados ubicados en los puertos o aeropuertos internacionales almacenar $\mathrm{y}$ vender mercancías nacionales o extranjeras, exentas del pago de tributos que las gravan, a los pasajeros que entran o salen del país o se encuentren en tránsito.

f) Las mercancías destinadas para el uso y consumo de los pasajeros y miembros de la tripulación a bordo de los medios de transporte de tráfico internacional, ya sean objeto de venta o no y las mercancías necesarias para el funcionamiento, conservación y mantenimiento de éstos, serán considerados como rancho de nave o provisiones de a bordo y se admitirán exentos del pago de derechos arancelarios y demás impuestos que gravan la importación.

g) El material especial para la carga, descarga, manipulación y protección de las mercancías en el Tráfico Internacional Acuático o Terrestre que ingrese y esté destinado a reexportarse en el mismo transporte, así como los repuestos y accesorios necesarios para su reparación, podrán ingresar sin el pago de derechos arancelarios ni impuestos que gravan la importación y sin la exigencia de presentación de garantía.

h) El material para uso aeronáutico destinado para la reparación o mantenimiento, los equipos para la 
los aeropuertos internacionales o lugares habilitados, en espera de su utilización, tanto en las aeronaves como en los servicios técnicos en tierra;

i) El ingreso y salida de contenedores para el transporte internacional de mercancías se rige por las disposiciones del Reglamento;

j) El ingreso, permanencia y salida de los muestrarios para exhibirse en exposiciones o ferias internacionales se rigen por las disposiciones de su propia Ley y Reglamento. Los lugares autorizados para funcionar como recintos de exposiciones o ferias internacionales se consideran zona primaria para efectos del control aduanero;

k) El ingreso y salida del equipaje y menaje de casa se rigen por las disposiciones que se establezcan por Reglamento, en el cual se determinarán los casos en que corresponderá aplicar un tributo único de catorce (14\%) sobre el valor en aduana, porcentaje que podrá ser modificado por Decreto Supremo; 1) La modalidad de Transporte Multimodal Internacional, así como el funcionamiento y control de los Terminales Interiores de Carga (TIC), se sujetan a lo establecido en las disposiciones específicas que regulan la materia;

m) Las mercancías sin fines comerciales destinadas a personas naturales y cuyo valor FOB no exceda de un mil y 00/00 dólares de los Estados Unidos de América (US \$ 1000,00$)$ se someten al Régimen Simplificado de Importación;

n) El ingreso y salida del material de guerra se rige por sus propias normas. recepción de pasajeros, manipuleo de la carga y demás mercancías necesarios para la operatividad de las aeronaves nacionales o internacionales ingresa libre de derechos de aduana y demás tributos, siempre que se trate de materiales que no se internen al país y que permanezcan bajo control aduanero, dentro de los límites de las zonas que se señale en los aeropuertos internacionales o lugares habilitados, en espera de su utilización, tanto en las aeronaves como en los servicios técnicos en tierra.

i) El ingreso y salida de contenedores para el transporte internacional de mercancías se rige por las disposiciones del Reglamento.

j) El ingreso, permanencia y salida de los muestrarios para exhibirse en exposiciones o ferias internacionales se rigen por las disposiciones de su propia Ley y Reglamento. Los lugares autorizados para funcionar como recintos de exposiciones o ferias internacionales se consideran zona primaria para efectos del control aduanero.

$\mathrm{k}$. El ingreso y salida del equipaje y menaje de casa se rigen por las disposiciones que se establezcan por Reglamento, en el cual se determinarán los casos en que corresponderá aplicar un tributo único de catorce por ciento $(14 \%)$ sobre el valor en aduana, porcentaje que podrá ser modificado por decreto supremo.

De conformidad con el Artículo 1 del Decreto Supremo No 096-2008-EF, publicado el 08 julio 2008 , se establece en catorce por ciento $(14 \%)$ el porcentaje del tributo único a que se refiere el presente inciso. El citado Decreto entró en vigencia a los 10 dias útiles de su publicación en el Diario Oficial El Peruano, según su Segunda Disposición Complementaria Final.

1) La modalidad de Transporte Multimodal Internacional, así como el funcionamiento y control de los Terminales Interiores de Carga (TIC), se sujetan a lo establecido en las disposiciones específicas que regulan la materia.

11) Las mercancías sin fines comerciales destinadas a personas naturales y cuyo valor FOB no exceda US $\$ 1,000.00$ se someten al Régimen Simplificado de Importación.

$\mathrm{m})$ El ingreso y salida del material de guerra se rige por sus propias normas 
La nueva ley denomina a estos tratamientos especiales otros regímenes aduaneros o de excepción, la norma anterior los llamaba Destinos Aduaneros Especiales o de Excepción.

Lo relevante en este punto es que en el inciso c) se refiere a los envíos de entrega rápida transportados por empresas del servicio de entrega rápida, como un destino especial el cual está regulado por el Decreto Supremo No 011-2009-EF, que aprueba el Reglamento de Envíos de Entrega Rápida.

Este destino aduanero especial nace en cumplimiento de un compromiso asumido por el Perú en el inciso b) del artículo 5.7 del Capítulo 5 del Acuerdo de Promoción Comercial suscrito entre el Perú y los Estados Unidos aprobado mediante Resolución Legislativa N ${ }^{\circ} 28766$ puesta en ejecución por el Decreto Supremo No 009-2009-MINCETUR, publicado el 17 de enero de 2009. El Acuerdo entró en vigencia el 1 de febrero de 2009. 


\section{Conclusiones}

- La nueva ley recoge la denominación sobre regímenes aduaneros señalados en la norma comunitaria andina, Decisión No 671, referida a la Armonización de Regímenes Aduaneros de la Comisión de la Comunidad Andina (la cual tiene como base la diversa legislación de los países miembros, el Convenio de Kyoto, y legislación de la Unión Europea), alineándose a una denominación uniforme, la cual resulta importante para los objetivos de integración de la Comunidad Andina de Naciones

- La nueva ley de aduanas simplifica la denominación de los tratamientos legales que serán sometidas las mercancías, no haciendo diferencia entre régimen, operación y destinos especiales, tomando la única denominación de "regímenes".

- Las modificaciones a los plazos en los diversos regímenes aduaneros se han adecuado convenientemente a las prácticas comerciales imperantes en la actualidad.

- Los diversos supuestos que contenía el régimen de exportación temporal con la norma derogada, han sido divididos y se han formado tres regímenes aduaneros, el de reimportación en el mismo Estado (ubicado dentro de los regímenes de importación), el régimen de exportación temporal para reimportación en el mismo Estado y el régimen de exportación temporal para perfeccionamiento pasivo (ubicado dentro de los regímenes de perfeccionamiento).

- La nueva ley ha mantenido la figura del tránsito interno, que fue reincorporado a nuestra legislación mediante la Ley No 28977 Ley de facilitación del comercio exterior. 


\section{BIBLIOGRAFÍA}

- BASALDUA Xavier. Derecho Aduanero. Buenos Aires: Abeledo Perrot, 1992.

- CABELLO PÉREZ, Miguel. Las Aduanas y el Comercio internacional. Madrid: ESIC editorial, 2009.

- CARBAJAL CONTRERAS, Máximo. Derecho Aduanero. Mexico DF: Editorial Porrúa, 2004.

- COSIO JARA, Fernando. Comentarios a la Ley General de Aduanas. Lima: Editorial Rodhas SAC, 2006.

- COSIO JARA, Fernando. Manual de Derecho Aduanero. Segunda edición. Lima: Editorial Rodhas SAC, 2007.

- MORA MARÍN, Alberto José. Regimenes Aduaneros. Lima: Secretaría General de la Comunidad Andina Proyecto de Cooperación UE-CAN, 2007.

- ROHDE PONCE, Andrés. Regimenes, contribuciones y procedimientos aduaneros. Primera edición. México: Ediciones Fiscales ISEF, 2000.

- ZAGAL PASTOR Roberto. Derecho Aduanero. Operativa de comercio exterior y regimenes aduaneros. Lima: Editorial San Marcos, 2009. 
